\title{
Impact of oil-based drill mud disposal on benthic foraminiferal assemblages on the continental margin off Angola
}

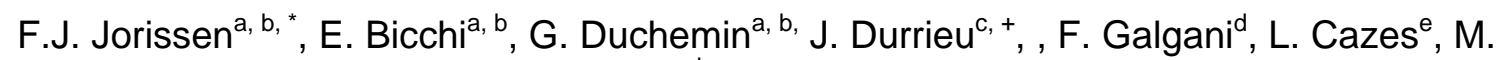 \\ Gaultier $^{\mathrm{a}, \mathrm{b}}$ and R. Camps ${ }^{\mathrm{c}}$
}

\footnotetext{
a Laboratory of Recent and Fossil Bio-Indicators (BIAF), UPRES EA 2644, Angers University, 2 Boulevard Lavoisier, 49000 Angers cedex, France

${ }^{b}$ LEBIM, Port Joinville, lle d'Yeu, France

c TOTAL EP, Département Environnement, Avenue Larribau, 64018 Pau, France

d IFREMER, Centre de Méditerranée, ZP de Brégaillon BP no 330, 83507 La Seyne sur Mer, France

e AJILON Engineering, Pau, France

+ Josiane Durrieu, who was strongly involved in this collaborative research from the very beginning, sadly passed away on the 18th of March, 2009. Her co-authors dedicate this paper to her memory.
}

*: Corresponding author : F.J. Jorissen, Tel.: +33 55684 8384; fax: +33 55684 0848, email address : frans.jorissen@univ-angers.fr

\begin{abstract}
:
In order to assess the possible environmental impact of oily cuttings discharged during oil exploration activities, we studied the benthic foraminiferal faunas in a five-station, 4-km-long sampling transect around a cuttings disposal site at about $670 \mathrm{~m}$ depth offshore Angola (W Africa), where drilling activities started 1.5 years before sampling. Living (Rose Bengal stained) and dead foraminiferal faunas were sampled in March 2006. The faunal patterns mirror the spatial distribution of hydrocarbons, which are dispersed into a southeastern direction. Four different areas can be distinguished on the basis of the investigated faunal parameters (density, diversity and species composition of the living fauna, and comparison with subrecent dead faunas). The fauna at station S31, $300 \mathrm{~m}$ SE of the oil cuttings disposal site, appears to be clearly impacted: the faunal density and diversity are maximal, but evenness is minimal. Taxa sensitive to organic enrichment, such as Uvigerina peregrina, Cancris auriculus and Cribrostomoides subglobosus, have largely disappeared, whereas the low-oxygen-resistant taxon Chilostomella oolina and opportunistic buliminids and bolivinids attain relatively high densities. At station S32, $500 \mathrm{~m} \mathrm{SE}$ of the disposal site, environmental impact is still perceptible. The faunal density is slightly increased, and U. peregrina, apparently the most sensitive species, is still almost absent. The faunas found at 1 and $1.8 \mathrm{~km} \mathrm{SE}$ of the disposal site are apparently no longer impacted by the drill mud disposal. Faunal density and diversity are low, and the faunal composition is typical for a mesotrophic to eutrophic upper slope environment. Finally, Station S35, $2 \mathrm{~km} \mathrm{NW}$ of the disposal site, contains an intermediate fauna, where both the lowoxygen-resistant $C$. oolina and the more sensitive taxa ( $U$. peregrina, $C$. auriculus and $C$. subglobosus) are present. All taxa live close to the sediment-water interface here, indicating a reduced oxygen penetration into the sediment. Since the hydrocarbon concentration is low at this station, it appears that the faunal characteristics are the consequence of a slightly different environmental setting, and not due to a contamination with drill cuttings. Our data underline the large potential of benthic foraminifera as bio-indicators of anthropogenic enrichment in open marine settings, such as caused by the disposal of oily drill cuttings. The foraminiferal faunas react essentially by a density increase of a number of tolerant and/or opportunistic taxa, and a progressive disappearance of more sensitive taxa in the most impacted area. Rather surprisingly, large-sized taxa appear to be more sensitive than small-sized foraminiferal taxa.
\end{abstract}

Keywords: Benthic foraminifera; Bio-indicators; Drill cuttings; Offshore Angola; Upper continental slope; W Africa 


\section{Introduction}

In the last decennia several methods for monitoring the impact of drill cuttings contamined with oil-based drilling fluids on the benthic ecosystem in open marine environments have been developed (e.g. Davies et al., 1984; Dicks et al., 1988; Gray et al., 1990; Daan et al., 1994; Olsgard and Gray, 1995; Shimmield et al. 2000; Gage, 2001; Grant and Briggs, 2001; Borja et al., 2003; Breuer et al., 2004; Dalmazzone et al., 2004; Durrieu and Bouzet, 2004; Muxika et al., 2005; Durrieu at al., 2006; Gass and Roberts, 2006; Flaten et al., 2007; Olsen et al., 2007). These methods are based on the analysis of benthic meiofauna and macrofauna, on the physico-chemical analysis of the sediment and/or on ecotoxicological tests on macrofauna, such as molluscs, annelids, crustaceans or nematodes. Theoretically, pollution by oily drill cuttings may have various impacts on the marine environment:

The degradation in the benthic environment of the oil adhering to the drill cuttings will increase the availability of organic compounds in the benthic ecosystem. This organic matter may serve as food source for benthic organisms, either directly or after partial conversion by bacterial consortia. Eutrophicated conditions will be the result, which may favour more opportunistic taxa.

This increased organic load may also lead to a higher sediment oxygen demand, which can eventually result in strongly hypoxic, or even anoxic conditions, especially in the immediate vicinity of the disposal site. Such conditions will further increase the selective pressure on the benthic faunas. Only taxa capable of anaerobic metabolism, or taxa having established symbiotic relationships with anaerobic organisms, will be capable to survive in fully anoxic conditions. Total anoxia may also lead to the presence of toxic sulphides at the sedimentwater interface.

In spite of the use of highly biodegradable oils with a low toxicity, the hydrocarbons used for oil drill fluids may still contain some toxic components. In cases of strongly hypoxic or anoxic conditions, with a presence of sulphides, the combination of various stress factors may ultimately cause a total disappearance of the benthic fauna, including the most resistant taxa.

In earlier studies, foraminifera have been used as bio-indicators of the environmental impact of oil spills, on the inner continental shelf (Casey et al., 1980) as well as in intertidal areas (Buckley et al., 1974; Vénec-Peyré et al., 1981; Morvan et al., 2004). Locklin and Maddocks (1982) were the first to use benthic foraminifera as bio-indicators of the impact of oil production platforms on the surrounding benthic environment. Their study on SW Louisiana inner shelf (water depth 6 to $98 \mathrm{~m}$ ) suggested a limited negative impact of the oil drilling activities in this naturally stressed environment (Locklin and Maddocks, 1982). Recently, we proposed the use of benthic foraminifera as bio-indicators of pollution by oily drill mud disposal (Durrieu et al., 2006; Mojtahid et al., 2006). Our first studies, in continental shelf environments, show that the foraminiferal faunas have a clear response to the stressed conditions provoked by the introduction of hydrocarbons in the benthic environment and can therefore be successfully applied as bio-indicators to estimate the impact of the discharge of oily drill cuttings. After these very promising results on the continental shelf, the present study aims to test the applicability of benthic foraminifera as bio-indicators of this type of pollution in a much deeper upper continental slope setting.

In comparison to the most commonly used macrofaunal and meiofaunal organisms, benthic foraminifera present several advantages for bio-monitoring purposes:

They are numerous in all marine environments, in upper slope settings attaining standing stocks of several hundreds to thousands of individuals per $50 \mathrm{cc}$ (e.g. Fontanier et al., 2002), so that statistically significant assemblages can be collected in very small samples.

Benthic foraminiferal faunas are very diverse; 3000 to 4000 recent species exist (Murray, 2007), and up to 100 different taxa may be found at a single site. These various taxa occupy very different ecological niches. The surface sediment may be inhabited by epifaunal filter feeders, or by surface grazers, whereas deeper in the sediment, a succession of infaunal deposit feeders may be found. In the case of an environmental impact, taxa with different 
ecological strategies will respond in different ways, leading to important changes in the composition and functioning of the foraminiferal faunas.

Foraminifera are among the few benthic organisms that leave an excellent fossil record. The presence of such historical archives may be very useful in cases where no baseline study has been performed before the onset of the polluting activities. In such cases, the subrecent fossil fauna may be used to better know the natural fauna, and to determine which species have disappeared and which other species have invaded the area since the onset of pollution.

In the few areas impacted by drill mud disposal where benthic foraminifera have been studied (Durrieu et al., 2006; Mojtahid et al., 2006), they respond in various ways to the complex of stress factors:

Organic matter input generally may lead to a disappearance of the most sensitive taxa, and to a strong frequency increase of a limited number of more opportunistic species. Overall faunal density increases, and biodiversity will drop. In non eutrophicated environments, benthic foraminifera show a species succession in the top 2 to $10 \mathrm{~cm}$ of the sediment (e.g. Corliss, 1985; Jorissen, 1999). In case of eutrophication of the ecosystem, this microhabitat succession is strongly compressed, and species that usually live in the dysoxic niches deeper in the sediment may be found close to the sediment-water interface (e.g. Jorissen, 1999; Jorissen et al., 2007).

Most foraminiferal taxa are very tolerant to low oxygen conditions. Only at concentrations below $1 \mathrm{ml} / \mathrm{l}$ (and perhaps as low as $0.5 \mathrm{ml} / \mathrm{l}$ ), the least resistant taxa are no longer capable to cope with hypoxia (e.g. Murray, 2001; Jorissen et al., 2007). Beyond this critical threshold level, the most sensitive taxa start to disappear, and more resistant taxa progressively dominate the faunas. Several deep infaunal taxa, which normally live in hypoxic or even anoxic conditions at several $\mathrm{cm}$ depth in the sediment, have been shown to be capable of anaerobic metabolism, and to respire nitrates (Risgaard-Petersen et al., 2006). In case of strongly lowered oxygen concentrations, they will replace the less resistant taxa at the sediment-water interface.

The impact of chemical pollutants on foraminiferal faunas is still poorly known. In a laboratory study on the impact of oil on intertidal faunas, Ernst et al. (2006) showed that the toxicity of the oil components may lead to an increased mortality of the foraminiferal faunas, but that some species may also react by reproductive events, leading to a sudden rise of their densities, and a strong increase of their relative frequencies. Whereas some authors (e.g. Alve, 1991; Sharifi et al., 1991) have described an increased percentage of foraminifera with test anomalies at sites polluted with heavy metals, other studies (e.g. Stubbles et al., 1996) show that test anomalies do not systematically occur in such conditions, or suggest that the test anomalies could rather be a response to salinity deviations (e.g. Coccioni, 2000; Geslin et al., 2000; 2002).

Although in many studies on anthropogenic pollution, the foraminiferal faunas show a clear response, it is evident that different species are responding in different settings (for examples see Martin, 2000). In the naturally eutrophicated continental shelf environments off Gabon, in front of the Ogooué river (Durrieu et al., 2006), the foraminiferal response to oily drill mud disposal is not the same as at the more oligotrophic outer shelf site off Congo described by Mojtahid et al., (2006). As a function of to the trophic conditions of the natural environment, different species will dominate the natural, non-impacted, faunas at continental shelf and slope sites. Eutrophication will lead to a selection of the taxa inhabiting these areas, eliminating the more sensitive ones, and favouring the more tolerant, often opportunistic taxa. In view of the large differences between faunas with different organic flux regimes (e.g. De Rijk et al., 2000), it is evident that different indicator species of pollution have to be selected for different areas. It is impossible to have a universal set of marker species, that can be applied in very different ecological settings.

The aim of the present paper is to study, for the first time, the impact of the disposal of oily drill muds on benthic foraminiferal faunas in an upper slope environment, and to investigate whether these organisms can be used as bio-indicators of this type of pollution there. We were especially interested to identify both the most tolerant and the most sensitive taxa with 
respect to this type of environmental perturbation. For this purpose, we present here the results of a study on the benthic foraminiferal faunas across a 5 stations transect around an oil drill platform, at about $670 \mathrm{~m}$ depth, off Angola.

\section{Material and methods}

\subsection{Study Area}

The study area is located offshore Angola (NW Africa), in the Pazflor oil field, some $100 \mathrm{~km}$ off N'Zeto. The disposal site is positioned close to platform Perpetua-2, at $7^{\circ} 31.53$ 'S and $12^{\circ} 8.05^{\prime} \mathrm{E}$, at a water depth of about $670 \mathrm{~m}$. At this site, oil exploration activities started at the end of 2004. Five stations, between 300 and $2000 \mathrm{~m}$ from the disposal site, were sampled in March 2006 (Fig. 1).

The surface and shallow subsurface circulation in the study area is complex; it is dominated by the interaction of the system of equatorial currents, undercurrents and counter currents. The area is also under the influence of river runoff from the Congo River. The surface hydrography (Fig. 1) is dominated by the Angola Current (AC) and the Benguela Coastal Current (BCC). The AC flows southward along the African coast and is fed by the eastwardflowing, shallow subsurface warm South Equatorial Counter Current (SECC). The AC and $\mathrm{BCC}$ converge at approximately $15^{\circ} \mathrm{S}$, where they form a strong temperature and productivity gradient called the Angola-Benguela Front (ABF, see Uliana et al. 2002).

Oceanic and coastal upwelling cells, that vary strongly in time and space, are another major hydrographic feature off West Africa. The coastal upwelling season extends from May to September (Busalacchi and Picaut, 1983; Verstraete, 1985), with a secondary upwelling period occurring in December. High coastal productivity (>450 g C m$~^{-2} \mathrm{yr}^{-1}$ according to Wenzhofer and Glud, 2002) is restricted to a coastal area between 5 and $7^{\circ} \mathrm{S}$ (Lutjeharms and Meeuwis, 1987), where primary production values above $1 \mathrm{~g} \mathrm{C} / \mathrm{m}^{2} /$ day are observed

(Oregon State University, Ocean Colour Site: http/web.science.oregonstate.edu/ocean.productivity/index.php). Our sampling transect is positioned at the southern border of this area. The relatively high primary production here is assumed to be the result of the combination of coastal upwelling of subsurface oceanic waters rich in nitrate and phosphate and nutrient input from the Congo River, that carries large amounts of dissolved silica to the ocean (Van Bennekom and Berger, 1984; Schneider et al., 1997). Hardman-Mountford et al. (2003) indicate that surface water chlorophyll-a concentrations are high throughout the year, and show only minor seasonal variability. They indicate that it is not clear to what extent this year-round chlorophyll-a maximum is an artefact caused by the presence of sedimentary particles in the Congo River plume. The silica concentrations in the surface waters determine the dominant group of primary producers: diatoms are dominant in the river plume, whereas small dinoflagellates dominate the phytoplanktonic communities in areas not influenced by river outflow (Cadée, 1978, 1984). Coccolithophores and dinoflagellates are major phytoplankton components in the oceanic upwelling areas further to the south, off Angola (Shannon and Pillar, 1986).

The thermohaline circulation of the deeper water masses in the study area is strongly controlled by the sea floor topography. The Angola Basin is mainly bathed by warm and oxygen-rich North Atlantic Deep Water (NADW). The lower part of the NADW is mixed with up to $20 \%$ of eastward flowing Lower Circumpolar Water (LCPW, the upper component of Antarctic Bottom Water, AABW, see Braga et al., 2004), which is injected into the Angola Basin trough deep gaps in the mid-Atlantic ridge system, such as the Walvis Ridge (Schmiedl and Mackensen, 1997). Our $670 \mathrm{~m}$ deep site is bathed by the Antarctic Intermediate Water (AAIW). 


\subsection{Sample preparation and benthic foraminiferal data}

Samples were collected from 27 to 29 March 2006 at 5 stations around oil platform Perpetua-2. Sampling was carried out with a Van Veen grab at about $670 \mathrm{~m}$ depth. Station S31 to S34 are respectively positioned at $300 \mathrm{~m}, 500 \mathrm{~m}, 1 \mathrm{~km}$ and 1,8 km south-east of the disposal site, whereas station S35 is positioned $2 \mathrm{~km}$ north-west of the discharge point (Table 1, Fig. 1).

Hydrocarbon percentages and barium concentrations were measured in order to describe the dispersal of the oily drill muds. In fact, barium is added to the drill mud in order to increase its specific density. Because of its very low reactivity (Dalmazzone et al. 2004), Baconcentration is a good marker for the spread of the drill muds at the seafloor.

For each station, the Van Veen grab was subsampled; a core with an inner diameter of $4 \mathrm{~cm}$ (corresponding to a sampling surface of about $12.5 \mathrm{~cm}^{2}$ ) was collected and sliced every 0.5 $\mathrm{cm}$ until $3 \mathrm{~cm}$ depth and then every $1 \mathrm{~cm}$ until $7 \mathrm{~cm}$ depth. All samples were preserved in 95\% ethanol with $1 \mathrm{~g} / \mathrm{l}$ Rose Bengal to distinguish between live and dead specimens (Walton, 1952). In the laboratory, the collected samples were sieved over 63 and $150 \mu \mathrm{m}$ meshes. Since the residues in both size fractions (63-150 $\mu \mathrm{m}$ and $>150 \mu \mathrm{m}$ fraction) were particularly voluminous, the foraminiferal assemblages were concentrated by density separation using trichloroethylene $(D=1,46)$. This method, for which the efficiency was tested by Mojtahid et al. (2006), was necessary because of the presence of a large amount of faecal pellets and glauconitic grains that strongly diluted the foraminiferal assemblages.

Live foraminiferal faunas were picked and inventoried, separately for the $>150 \mu \mathrm{m}$ and 63$150 \mu \mathrm{m}$ fractions, in the top $3 \mathrm{~cm}$ of the sediment. Entire samples were examined under wet conditions ( $\sim 50 \%$ ethanol, $\sim 50 \%$ water $)$, and all brightly stained specimens were picked, determined and counted. For all stations, the density of the total faunas and of individual species, the species richness (number of species) and several diversity indices were calculated (species diversity S, natural log based Shannon-Wiener index $\mathrm{H}$, evenness $\mathrm{E}$, after Hayek and Buzas, 1997). Foraminiferal densities were standardised for a $10 \mathrm{~cm}^{2}$ surface area. We chose this specific area because it is close to the sampled surface of about $12.5 \mathrm{~cm}^{2}$. In order to determine the similarity of pairs of samples, we used Renkonen's Percent Similarity Index (Renkonen, 1938; see also Krebs, 1998), which is expressed as:

$S_{R}=\sum_{i=1}^{i=n} \min \left(p_{1 i}, p_{2 i}\right)$,

where $p_{1 i}$ is the percentage of species $i$ in sample 1 and $p 2_{i}$ is the percentage of species $i$ in sample 2. In fact, this is exactly the opposite as the Bray-Curtis percentage difference (BrayCurtis, 1957). In order to determine the significance of his Renkonen index values, Sanders (1960) made an inventory of average values of the Renkonen index in other studies. These average values (for all tested pairs of samples in each study) varied from 24 to 55 . It appears therefore that a percentage overlap above 50 indicates a high degree of similarity.

The total density of the living foraminiferal faunas has been determined by summing up the number of individuals for all levels between 0 and $3 \mathrm{~cm}$ depth. In order to compare our data with those of other studies, total faunal densities have been standardised for a $10 \mathrm{~cm}^{2}$ surface area. This specific value has been chosen because it is close to the sampled sediment surface (of $12.5 \mathrm{~cm}^{2}$ ), so that density differences between samples are real, and not biased by extrapolation to a much larger surface.

The dead assemblages of the $>150 \mu \mathrm{m}$ size fraction were studied for the $2-3 \mathrm{~cm}$ interval. We selected this interval for two reasons: 1 ) because it is very probably positioned below the layer of drill cuttings, which according to modelling results should have a thickness of less than $1 \mathrm{~cm}$ at all stations, and 2) because at this depth deeper infaunal taxa, which may live at several $\mathrm{cm}$ depth in the sediment, will not be under-represented in the dead fauna, such as may be the case in more superficial sediment levels (Loubere, 1989). We decided not to analyse the dead faunas of the 63-150 $\mu \mathrm{m}$ fraction, because dead tests from this size fraction are particularly sensitive to transport by bottom currents. Samples were dried and complete samples were picked for each station. In order to compare living and dead 
assemblages, all non-fossilising arenaceous taxa were omitted from the living and dead data sets. Since the densities of these taxa, that are not preserved, decrease rapidly to deeper sediment-layers (Bizon and Bizon, 1985; De Stigter et al., 1998), recent and dead faunas can only be compared directly if the non-fossilising taxa are excluded from the countings. After doing so, relative frequencies were calculated for all taxa on the basis of the corrected data sets. Finally, the percentage of living foraminifera ( $n^{\circ}$ living $/\left(n^{\circ}\right.$ living $+n^{\circ}$ dead individuals $)$ ) was calculated for all taxa.

The density and composition of the living assemblages give information about the current ecological conditions and about potential adaptations of the faunas to changes in physicochemical environmental parameters due to drill mud disposal. The dead assemblages constitute probably a mixture of pre-impact faunas and faunas that inhabited the area during the 1.5 years following the onset of oil drilling activities. The comparison of living and dead assemblages can therefore make it possible to recognize species indicative of the impact of oil drilling operations. Species that are found in the dead faunas, but that are absent, or infrequent, in the living faunas, may have disappeared because they do not tolerate the present anthropogenic environmental stress. Inversely, species that are much richer in the living than in the dead faunas may be favoured by the environmental impact due to drill cutting disposal. However, it should be kept in mind that also preservational differences between species, and different life strategies, can be responsible for important differences between living and time-averaged dead faunas (e.g. Murray, 1991; Jorissen and Wittling, 1999).

\section{Results}

\subsection{Sediment geochemistry}

The sediments are everywhere constituted of silty muds, extremely rich in faecal pellets and glauconitic grains. The sedimentary organic carbon content varies from 3.8 to $4.1 \%$, without a clear trend. The $\mathrm{C} / \mathrm{N}$ ratio varies from 6.8 to 8.5 , indicating a predominantly marine signature. The redox potential at the sediment surface is about $100 \mathrm{mV}$ at all 5 stations, suggesting a well oxygenated sediment-water interface (Sutherland et al., 2007).

Hydrocarbon and barium concentrations are shown on Fig. 2 and listed in Table 2. Total hydrocarbon concentration is maximum $\left(\sim 9.8 \mathrm{mg} \mathrm{g}^{-1}\right.$ dry weight) at station S31, nearest to the disposal site, and rapidly decreases with increasing distance from the well. The background hydrocarbon values, found beyond $1 \mathrm{~km}$ from the disposal sites, are about $1 \mathrm{mg}$ $\mathrm{g}^{1}$ dry weight. The same tendency is shown by the labile fraction of the hydrocarbon $(\mathrm{nC} 13$, nC15, nC16, nC17, nC19, nC20), who exhibits a maximum value (94 $\mu \mathrm{g} \mathrm{g}^{-1}$ dry weight) at station S31 and background levels of $10-20 \mu \mathrm{g} \mathrm{g}^{-1}$ at all stations more than $1 \mathrm{~km}$ away from the disposal site (Table 2).

The barium concentrations show a slightly different pattern (Table 2). Values around $0.5 \mathrm{mg}$ $\mathrm{g}^{-1}$ dry weight are found at all 4 stations SW of the disposal site (including station S34 at a distance of $2 \mathrm{~km}$ ). At station $\mathrm{S} 35$, on the contrary, the barium concentration is significantly lower (about $0.27 \mathrm{mg} \mathrm{g}^{-1}$ ).

\subsection{Living foraminiferal faunas}

A total of 86 species was distinguished in the $>150 \mu \mathrm{m}$ and $63-150 \mu \mathrm{m}$ size fractions (Appendix 1-2). Species provided with hyaline calcareous and agglutinated tests are present in about similar proportions, while species with a porcelaneous test are always very rare or even absent. In the $>150 \mu \mathrm{m}$ fraction, the total number of individuals found in the uppermost 3 $\mathrm{cm}$ of the sediment (investigated sediment surface $=12.5 \mathrm{~cm}^{2}$, total volume $=37,7 \mathrm{~cm}^{3}$ ) shows a conspicuous maximum of about 200 individuals at station S31, $300 \mathrm{~m}$ SE of the disposal site (Fig. 3a). This corresponds to about 160 individuals per $10 \mathrm{~cm}^{2}$. With increasing 
distance from the disposal site, foraminiferal numbers rapidly drop to about 75 ( 60 specimens per $10 \mathrm{~cm}^{2}$ ) at station S32 (500 m SE of the disposal site) and about 25 (20 specimens per $10 \mathrm{~cm}^{2}$ ) at station S34 (1.8 km SE of the disposal site). Also towards the northwest, the faunal density decreases, to about 60 individuals (about 50 individuals per $10 \mathrm{~cm}^{2}$ ) at station S35, at $2 \mathrm{~km}$ distance.

In the 63-150 $\mu \mathrm{m}$ fraction the total absolute number of individuals tends to be higher (Fig. $3 b)$ than in the larger fraction, with a maximum of about 215 specimens $(\sim 170$ specimens per $\left.10 \mathrm{~cm}^{2}\right)$ at station 31 . Foraminiferal densities are relatively high (140-190 individuals, $\sim 100-$ 150 individuals per $10 \mathrm{~cm}^{2}$ ) at stations S32 and S33, 0.5 and $1 \mathrm{~km} \mathrm{SW}$ of the disposal site, respectively. The lowest values ( 40 individuals, or about 30 specimens per $10 \mathrm{~cm}^{2}$ ) are found at station 34, $1.8 \mathrm{~km} \mathrm{SE}$ of the disposal site. At station S35, at $2 \mathrm{~km} \mathrm{NW}$ of the disposal site, about 110 individuals are found ( -85 specimens per $\left.10 \mathrm{~cm}^{2}\right)$.

The diversity indices (species richness S, Shannon-Wiener index $\mathrm{H}$ and evenness $\mathrm{E}$ ) for the $>150 \mu \mathrm{m}$ and 63-150 $\mu \mathrm{m}$ fractions are shown on figure 4 . In both fractions the species richness attains a maximum value at station S31 (39 for the $>150 \mu \mathrm{m}$ fraction and 36 for the 63-150 $\mu \mathrm{m}$ fraction, respectively). Except for station S31, close to the disposal site, the species richness is everywhere slightly higher in the 63-150 $\mu \mathrm{m}$ fraction than in the $>150 \mu \mathrm{m}$ fraction. To the SE and to the NW, the species richness decreases progressively with increasing distance from the disposal site. Minimum value of 10 and 20 species, respectively, are found in the $>150 \mu \mathrm{m}$ and $63-150 \mu \mathrm{m}$ fractions of station S34.

In the $>150 \mu \mathrm{m}$ fraction of station S31 (Fig. 4a), the Shannon-Wiener index is maximal (30), whereas the evenness (Hayek and Buzas, 1997) is minimal (0.5). In both directions (to the NW and SE), the evenness slightly decreases (to a minimum of 19 at station S34, $1.8 \mathrm{~km}$ to the SE). Inversely, evenness progressively increases in both directions, and attains maximum values of about 0.75 at stations S35 and 0.70 at station S34, $2 \mathrm{~km} \mathrm{NW}$ and $1.8 \mathrm{~km}$ SE of the disposal site, respectively.

The diversity patterns for the 63-150 $\mu \mathrm{m}$ size fraction are more complex. The Shannon-Wiener index varies from 28 to 21 , with a maximum at station 31, and a minimum at station S35 (Fig. 4b) The evenness shows a strong maximum (of 0.7) at station S34, 1.8 $\mathrm{km}$ SE of the disposal site. For all other stations the Shannon-Wiener index varies between 0.4 and 0.5 .

In the $>150 \mu \mathrm{m}$ fraction the dominant species are Bolivina albatrossi, Bulimina aculeata/marginata, Cancris auriculus, Chilostomella oolina, Cribrostomoides subglobosus, Globobulimina affinis, Karreriella bradyi, Reophax scorpiurus and Uvigerina peregrina (Fig. 5; appendix 1). The absolute and relative densities of these taxa vary as a function of the distance to the disposal site. At station S31, nearest to the disposal site (300 m NE), the faunal assemblage is dominated by Reophax scorpiurus $(\sim 15 \%)$ Chilostomella oolina $(\sim 13 \%)$, Karreriella bradyi $(\sim 11 \%)$, and Globobulimina affinis $(\sim 11 \%)$. To the south-east (stations S32- S33 -S34) Reophax scorpiurus decreases slightly, and attains a minimum value of $\sim 5 \%$ at S32. Chilostomella oolina is absent at all other stations, except for some specimens found at station S35. Karreriella bradyi is a dominant faunal element at stations S32 ( 21\%) and S34 (32\%). Globobulimina affinis is present with comparable percentages $(8-18 \%)$ at all stations, without a clear trend.

Uvigerina peregrina, which is rare at station S31 (2\%), shows a very clear increase towards the stations farther away of the disposal site, and attains a maximum of $24 \%$ at station S34. Also Cancris auriculus (1\%) and Cribrostomoides subglobosus (1\%) show minimal percentage values at station S31, close to the disposal site. Cancris auriculus shows a clear increase in SE direction (12-19\% at stations S32-S34), but a slightly lower value (7\%) at station S35, $2 \mathrm{~km} \mathrm{NW}$ of the disposal site. The agglutinated taxon Cribrostomoides subglobosus shows a comparable trend, with maximum densities at stations S32 and S33 (18\% and $9.5 \%$, respectively), and slightly lower values ( $4 \%)$ at the two farthest stations. At station S35, $2 \mathrm{~km} \mathrm{NW}$ of the disposal site, the fauna is dominated by Globobulimina affinis (18\%), Uvigerina peregrina (13\%) and Reophax scorpiurus (12\%). The fauna of this station shows some resemblance with that of station S31. In particular, the species Bolivina albatrossi (7\%) and Chilostomella oolina (5\%) are only present at these two stations. 
The main species of 63-150 $\mu \mathrm{m}$ fraction are Bolivina albatrossi, Bolivina pseudoplicata, Brizalina earlandi, Bulimina rostrata, Gyroidinoides orbicularis and Nuttallides pusillus (Fig. 6; Appendix 2). The fauna contains some juvenile specimens of taxa mainly found in the $>150$ $\mathrm{m}$ fraction, such as Bulimina marginata, Cancris auriculus and Uvigerina peregrina, but is mainly composed of adult representatives of a number of small-sized taxa.

At station S31, closest to the disposal site, Bulimina albatrossi shows a higher value $(\sim 8 \%)$ than at the other south-eastern stations (average $\sim 3 \%$ ); it is even absent at station S35, 2 $\mathrm{km}$ NW of the disposal site. Also Bolivina pseudoplicata ( $8 \%)$ and Bulimina rostrata ( $6 \%)$ are richer at station S31 than at all others stations.

Bolivina spathulata, present at all stations, attains a maximum value at station S35 ( 27\%). At the stations between 300 and $1000 \mathrm{~m}$ from the disposal site (S31-S33), its percentage varies from 10 to 15\%. Nuttallides pusillus and Gyroidinoides orbicularis are present at all stations with a maximum at station S33 ( $40 \%$ and 15\% respectively).

When considering the vertical distribution in the superficial sediment (microhabitat), it can be observed that at station S31, $300 \mathrm{~m} 4 \mathrm{SE}$ of the disposal site, the fauna of the $>150 \mu \mathrm{m}$ fraction is strongly concentrated in the upper $1 \mathrm{~cm}$ of the sediment (Fig. 5). In the next two south-eastern stations (S32 and S33), living specimens are found down to a depth of two cm. At station S34, $1.8 \mathrm{~km}$ SE of the disposal site, living foraminifera are again largely limited to the topmost $\mathrm{cm}$. At station S35, $2 \mathrm{~km} \mathrm{NW}$ of the disposal site, the fauna shows a strong maximum in the first $0.5 \mathrm{~cm}$, but low densities of living specimens are found down to $2.5 \mathrm{~cm}$ depth.

The fauna of the 63-150 $\mu \mathrm{m}$ fraction shows a much more homogeneous vertical distribution in the topmost 2 to $3 \mathrm{~cm}$ (Fig. 6). At station S31, the abundant living fauna shows a density maximum between 0.5 and $1 \mathrm{~cm}$ depth. A similar infaunal maximum can be observed at station S32. The two most distal stations (S34 and S35), on the contrary, show a maximum density in the topmost level. At station S31 the maximum abundance of Bolivina spathulata, which at all other stations is found in the first half centimetre, is found between 0.5 and $1 \mathrm{~cm}$ depth. The vertical distribution of Bulimina rostrata is interesting: at stations S31 to S33 (300 $\mathrm{m}$ to $1000 \mathrm{~m}$ from the disposal site) this species is concentrated in the upper 1 to $2 \mathrm{~cm}$, whereas at stations S 34 and S35, farthest away from the disposal site, it is mainly found in the $0-0.5 \mathrm{~cm}$ interval.

Finally, we have compared the faunal composition at our five stations by using the Renkonen percent similarity index (Table 3 ). Values above $50 \%$ indicate a high degree of similarity (Sanders, 1960). For the $>150 \mu \mathrm{m}$ fraction faunas, a rather high similarity (from 53 to 62) was found between stations S32, S33 and S34, positioned between 500 and $2000 \mathrm{~m}$ SE of the disposal site (Table 3a). Rather surprisingly, also station S31, nearest to the disposal site, and S35, (2000 m NW of the disposal site, show a relatively high Renkonen index, of about 53 , indicative of a fairly high degree of similarity between the faunas of these two stations. In the $63-150 \mu \mathrm{m}$ fraction faunas, all stations exhibit fairly high similarity indices (47-70, Table 3b).

\subsection{Dead foraminiferal faunas}

The dead foraminiferal faunas have exclusively been studied in the $>150 \mu \mathrm{m}$ fraction, in the 2-3 cm depth level. Overall, 68 different taxa have been identified (Appendix 3). All dead faunas are strongly dominated by Bulimina aculeata/marginata, Bolivina spathulata and Uvigerina peregrina. These taxa are accompanied by significant quantities of Bolivina albatrossi, Bulimina inflata/costata, Chilostomella oolina and Globobulimina affinis (Fig. 7). The Renkonen percent similarity index (Table $4 \mathrm{a}$ ) is always very high (>77), indicating a very high similarity of the composition of the dead foraminiferal faunas. Only minor differences exist between our five sampling stations: Globobulimina affinis shows a relative frequency increase (from $2.5-4 \%$ to about $7 \%$ ) at the north-western station S35, whereas Bolivina albatrossi is slightly enriched ( $\sim 9 \%)$ at station S32. 
At station S31, closest to the disposal site, we analysed the composition of the dead foraminiferal faunas for 5 different depth levels, between 1 and $7 \mathrm{~cm}$ depth in the sediment (Appendix 3). Again, Renkonen's percent similarity index is always very high (>68), showing a very high similarity in the faunal composition of the 5 investigated depth levels (Table 4b). At all levels, Bulimina aculeata/marginata (20-26\%), Bolivina spathulata (10-21\%) and Uvigerina peregrina (13-23\%) are the most abundant species. Bulimina inflata/costata, Bolivina albatrossi and Globobulimina affinis are always represent $<10 \%$ of the assemblage. We calculated living/total (living + dead) ratios for all species occurring with a relative proportion above $5 \%$ in the dead or living assemblage (Table 5). Non-fossilising agglutinated taxa (e.g. Cribrostomoides spp., Reophax spp.) were omitted from the data tables before calculation of L/T-ratios, because of the rapid disintegration of their test after death. On the basis of the L/T-ratios presented in Table 5, three different patterns can be distinguished:

When they are present both in the living and dead faunas, Chilostomella oolina, Globobulimina affinis, Cancris auriculus, Bolivina albatrossi and Karreriella bradyi are always much richer in the living than in the dead fauna ( $L / T>60 \%)$.

Bolivina spathulata, Bolivina inflata/costata and Bulimina aculeata/marginata are always much richer in the dead than in the living assemblages.

Finally, Uvigerina peregrina has comparable relative densities in the living and dead faunas at stations at $1 \mathrm{~km}$ or more from the disposal site, whereas it is much richer in the dead fauna in the two stations (S31, S32) closest to the disposal site.

\section{Discussion}

\subsection{Sediment geochemistry}

The sediment at our $670 \mathrm{~m}$ deep oil drill mud disposal site is characterised by elevated concentrations of barium and hydrocarbons. Barium is a major component of most drilling fluids, is more or less inert in the marine environment, and can therefore be used as a passive tracer of drill mud dispersal. Hydrocarbons are responsible for an eutrophication of the benthic environment. Their more labile components will rapidly be degraded in the oxic environments at the sediment-water interface and in the uppermost sediment layers, thereby causing a significant increase of the sediment oxygen demand. The more refractory, less bioavailable components may be partially degraded by anaerobic mechanisms deeper in the sediment. The toxicity of some of the hydrocarbon components may be an additional factor of environmental stress, making the environmental conditions particularly unfavourable for the benthic fauna.

The distribution patterns of total hydrocarbons and barium (Fig. 2) suggest a dispersal of the drill muds in south-eastern direction. The fairly high barium concentrations, of about $0.5 \mathrm{mg} / \mathrm{g}$ dry weight, found up to $1.8 \mathrm{~km}$ SE of the oil platform, suggest long distance transport of this material by bottom currents. Hydrocarbon concentrations decrease more rapidly with increasing distance from the disposal site. At $1 \mathrm{~km}$ to the southeast, values have dropped to the background level. The rapid decrease of hydrocarbon concentrations to the southeast, which contrasts with the pattern shown by the barium concentrations, is probably due to the rapid degradation of most of the hydrocarbons shortly after their disposal. Such a rapid degradation can be expected for the highly biodegradable oils used at this exploration site.

\subsection{Foraminiferal faunas: density}

The samples used for our foraminiferal study were taken with a Van Veen grab. This is not the ideal tool to sample undisturbed deep-sea sediments (e.g. Bett et al., 1994). The bow wave effect and washout during the rise of the sampling gear through the water column may lead to a partial loss of the superficial sediment in which many of the foraminifera dwell. This phenomenon would lead to decreased faunal densities, which would affect surface dwelling- 
dwelling species more than infaunal taxa. In order to see whether such a phenomenon has caused a severe decrease of faunal densities in our samples, we will in the following paragraphs compare our faunal densities with data observed in other areas in similar settings.

Another problem is the fact that our study is based on unreplicated samples of a fairly small surface area (about $12.5 \mathrm{~cm}^{2}$ ). In order to avoid over-interpreting our data, we did not extrapolate our data to a larger surface area, but standardised our data for a $10 \mathrm{~cm}^{2}$ surface. Furthermore, because our data are based on the study of a fairly small surface, we consistently tried to be conservative in our interpretations.

The observed foraminiferal densities for the $>150 \mu \mathrm{m}$ fraction (Fig. 3) mirror the total hydrocarbon distribution (Fig. 2). The total foraminiferal density at the stations located 1 to 2 $\mathrm{km}$ away from the disposal site varies from 20 to 50 individuals per $10 \mathrm{~cm}^{2}$; at $300 \mathrm{~m}$ SE of the disposal site a maximum foraminiferal density of 160 individuals per $10 \mathrm{~cm}^{2}$ is observed. Our background values (stations S33, S34 and S35) are comparable to the densities of 30 to 60 individuals per $10 \mathrm{~cm}^{2}$ observed by Licari and Mackensen (2005) at upper slope stations in the northern Angola Basin (latitude $0^{\circ}-10^{\circ} \mathrm{S}$ ). They are lower than the foraminiferal densities exceeding 100 individuals per $10 \mathrm{~cm}^{2}$ observed by Schmiedl et al. (1997) in shelf and upper continental slope environments off southwest Africa. Fontanier et al. $(2003 ; 2006)$, who studied the seasonal variability of benthic foraminifera at two open slope stations in the Bay of Biscay (NE Atlantic) found densities from 35 to 200 individuals per $10 \mathrm{~cm}^{2}$ at a $550 \mathrm{~m}$ deep station and from 25 to 90 individuals per $10 \mathrm{~cm}^{2}$ at a $1000 \mathrm{~m}$ deep station. Maximal densities were found shortly after major phytoplankton blooms in the surface waters. Summarizing, the comparison of our foraminiferal densities with those of comparable areas shows that our background values fall within the range of described literature data, and are situated at the lower end of this range. The density of 150 foraminifera per $10 \mathrm{~cm}^{2}$, observed $300 \mathrm{~m}$ southeast of the disposal site, on the contrary, corresponds to the highest values described in the literature for comparable upper slope settings. In natural conditions, such values are only reached after major surface phytoplankton blooms, and the subsequent transport of the phytoplankton remains to the ocean floor (Fontanier et al., 2006). It appears that in our study area, the strongly increased faunal density close to the disposal site is the result of a strongly localized ecosystem eutrophication, due to the introduction of important amounts of hydrocarbons adhering to the drill muds. A similar phenomenon has been described by Mojtahid et al. (2006), who observed maximum densities (170 individuals per $10 \mathrm{~cm}^{2}$, compared to background values of 6 to 40 individuals per $10 \mathrm{~cm}^{2}$ ) at a station impacted by drill cutting disposal at the outer continental shelf off Congo.

Much less literature data are available on the foraminiferal densities of the 63-150 $\mu \mathrm{m}$ fraction. Fontanier et al. $(2003,2006)$ studied the foraminiferal faunas in this size fraction in the uppermost $0.5 \mathrm{~cm}$ of the sediment at upper slope settings in the Bay of Biscay, between October 1997 and may 2000. At $550 \mathrm{~m}$ depth, they describe maximum values of 300 individuals per $10 \mathrm{~cm}^{2}$ during eutrophic periods (spring and autumn bloom), which strongly contrast with minimum values of only $5-10$ individuals per $10 \mathrm{~cm}^{2}$. At $1000 \mathrm{~m}$ depth, foraminiferal densities vary from about 10 to 150 individuals per $10 \mathrm{~cm}^{2}$. Duchemin et al., (2007), who studied the foraminiferal fauna in the uppermost $1 \mathrm{~cm}$ at the same two stations in May 2004 (after the spring phytoplankton bloom), found densities of $\sim 400$ and $\sim 140$ individuals per $10 \mathrm{~cm}^{2}$ at $550 \mathrm{~m}$ and $1000 \mathrm{~m}$ depth, respectively. Since in our study, the large majority of the living specimens of the 63-150 $\mu \mathrm{m}$ fraction are found in the topmost $\mathrm{cm}$, we can compare our results with those described in the afore-mentioned studies (Fontanier et al., 2003; 2006; Duchemin et al. 2007). Our lowest values, of $\sim 30$ and $\sim 85$ specimens per $10 \mathrm{~cm}^{2}$, found at stations at about $2 \mathrm{~km}$ from the disposal site, are higher than the minimal values described in the earlier studies. Our maximum values, of 100 to 170 individuals per 10 $\mathrm{cm}^{2}$, on the contrary, are lower than the foraminiferal densities recorded after phytoplankton bloom periods. Again, our highest foraminiferal densities in the vicinity of the disposal site appear to be a response to localized ecosystem eutrophication.

Summarising, it appears that our faunal densities are in both size fractions comparable with those found in areas with a similar oceanographic setting. This suggests 
that our data are not seriously biased due to a loss of superficial sediment by sampling with a Van Veen grab.

\subsection{Foraminiferal faunas: diversity}

In the $>150 \mu \mathrm{m}$ fraction, both the species number and the Shannon-Wiener index indicate a maximum faunal diversity at station S31, $300 \mathrm{~m}$ southeast of the disposal site. Both indices decrease with increasing distance from the disposal site. The evenness shows an inverse trend; it is minimal at station S31, and increases towards the northwest and southeast. The low evenness close to the disposal site indicates that the faunas are strongly dominated by a limited number of species there. The increased species number and Shannon-Wiener index suggest that at station S31, local eutrophication has favoured the arrival of some more opportunistic taxa, but conditions are apparently not enough stressed to cause the disappearance of the more sensitive taxa of the baseline fauna. A similar situation, with maximum diversity values being found at moderately impacted sites, has earlier been described by Pearson and Rosenberg (1978) for macrofauna at a sewage disposal site in the Firth of Clyde (Scotland). More recently, Muxika et al., (2005), who tested the suitability of a marine biotic index based on macrobenthos (AMBI) for monitoring the impact of oil drilling activities, observed a similar trend at several continental shelf sites in the central and northern North Sea, at 100 to 150 m depth.

The faunal diversity indices calculated on the basis of the composition of the $63-150 \mu \mathrm{m}$ fraction show a more or less similar pattern. Both the species diversity and Shannon-Wiener index are maximal at station S31, but differences between stations are smaller than in the larger size fraction. Rather surprisingly, evenness is maximal at station S34, $2 \mathrm{~km}$ southeast of the disposal site.

\subsection{Foraminiferal faunas: species composition and vertical distribution}

At stations S33 and S34, positioned respectively 1 and $2 \mathrm{~km}$ SE of the disposal site, the faunas of the $>150 \mu \mathrm{m}$ fraction are dominated by Uvigerina peregrina, Karreriella bradyi, Cancris auriculus, Globobulimina affinis and Cribrostomoides subglobosus, whereas Nuttallides pusillus, Bolivina spathulata, Brizalina earlandi and Gyroidinoides orbicularis dominate the 63-150 $\mu \mathrm{m}$ fraction. All these taxa are typical of upper continental slope environments. At station S31, $300 \mathrm{~m}$ SE of the disposal site, where the faunal density is maximal, $U$. peregrina, $C$. auriculus and $C$. subglobosus have almost disappeared, whereas Chilostomella oolina, Reophax scorpiurus (both > $150 \mu \mathrm{m}$ fraction), Bolivina albatrossi and Bolivina pseudoplicata (both 63-150 $\mu \mathrm{m}$ fraction) have become dominant faunal elements. $C$. oolina is totally absent at all other stations SE of the disposal site. The fauna of stations S32, $500 \mathrm{~m}$ SE of the disposal site, shows intermediate characteristics. Although the relative frequency of $U$. peregrina is already low (4\% in comparison to $14-24 \%$ observed at stations S33 and S34), C. auriculus is still present with a high relative frequency. The maximum percentage of $C$. subglobosus at this station is remarkable. Also the faunal composition at station S35, $2 \mathrm{~km} \mathrm{NW}$ of the disposal site, shows somewhat intermediate characteristics. Because of the presence of $C$. oolina and the low percentages of $C$. auriculus and $C$. subglobosus, the faunas resemble those of station S31, but the elevated percentage of $U$. peregrina and the low relative frequencies of $B$. albatrossi and $B$. pseudoplicata are more similar to the faunas found at stations S33 and S34.

These results are confirmed by the Renkonen percent similarity index. For the $>150$ $\mu \mathrm{m}$ fraction, stations S32, S33 and S34 show a high similarity, and a fairly low similarity with the faunas of station S31. Station S35 is the only one to show a fairly high similarity with station S31. The generally much higher Renkonen indices in the 63-150 $\mu \mathrm{m}$ fraction indicate that the faunas of this smaller size fraction are much more similar than those of the large size fraction. This could indicate that large-sized taxa are more sensitive to this type of environmental impact than the small-sized taxa. 
The data on the vertical distribution of the foraminiferal faunas in the topmost sediment show that the $>150 \mu \mathrm{m}$ fraction has a maximum density in the topmost $1 \mathrm{~cm}$ at all stations. Only at station $\mathrm{S} 35$, the second half $\mathrm{cm}(0.5-1.0 \mathrm{~cm}$ depth) shows already a very strong frequency decrease. In the 63-150 $\mu \mathrm{m}$ fraction, the surface maximum is less obvious, but still distinct at stations S31 (top $1 \mathrm{~cm}$ ), S34 and S35 (both top $0.5 \mathrm{~cm}$ ). A more homogenized distribution, with about equal foraminiferal densities down to about $2 \mathrm{~cm}$ depth, can be seen at stations S32 and S33. The strong concentration of living foraminifera in the topmost $0.5 \mathrm{~cm}$ at station $\mathrm{S} 35,2 \mathrm{~km} \mathrm{NW}$ of the disposal site, could reflect a very shallow position of the zero oxygen level, which limits the vertical penetration of most taxa (Jorissen et al., 1995; 2007). The fact that at the four other stations, maximum densities are found in the two uppermost levels (00.5 and $0.5-1 \mathrm{~cm}$ depth) suggests that oxygen penetration is slightly deeper there. This would point to a slightly different environmental setting at the north-western station S35, which could partly explain some of the common features between the faunas at this station and at station S31.

\subsection{Dead foraminiferal assemblages}

In contrast to the living assemblages, which represent a snapshot of the foraminiferal faunas in a particular environmental context, that may vary considerably over short periods of time, the dead assemblages give a time-averaged image of the foraminiferal faunas. In comparison with the living faunas, the dead faunas will have been transformed by taphonomical losses, that affect some taxa much more than others (Denne and Sen Gupta, 1989. Jorissen and Wittling, 1998). In particular, most of the agglutinated taxa disappear rapidly over time (Bizon and Bizon, 1985). Taphonomical differences may also affect taxa with calcareous tests, with robust, thick-walled taxa being much better preserved than very fragile thin-walled species (Murray, 1991). Unfortunately, we have no data on the sediment accumulation rate, and we do not know the exact thickness of the deposited layer of drill cuttings either. In comparable upper slope settings, accumulation rates of 4 to $15 \mathrm{~cm} / \mathrm{ky}^{-1}$ have been calculated (Giraudeau et al., 1998). If we hypothesise a similar sedimentation rate for our station, then the 2 to $3 \mathrm{~cm}$ depth level, for which we studied the composition of the dead faunas, would contain a mixture of specimens deposited between 10 and 50 years ago, perhaps partially mixed with more recent tests introduced by macrofaunal bioturbation. In view of the quantity of deposited drill cuttings, and their modelled dispersal at this $570 \mathrm{~m}$ deep site (during their fall though the water column and after their arrival on the sea floor), the thickness of the layer of drill cuttings should be less than $1 \mathrm{~cm}$ everywhere. At station S35, where Ba-contents are minimal, there has probably been no deposit of drill cuttings. The dead fauna at 2-3 cm depth should therefore mainly contain the remains of foraminifera which have been living in the area before the onset of the oil exploration activities.

The dead faunas of the $>150 \mu \mathrm{m}$ fraction are at all stations strongly dominated by Bulimina aculeata/marginata, Uvigerina peregrina and Bolivina spathulata. Of these three taxa, only $U$. peregrina is also a dominant element in the living fauna. The other taxa that dominate the living faunas, Cancris auriculus, Chilostomella oolina, Globobulimina affinis, Cribrostomoides subglobosus and Karreriella bradyi are all low frequent in the dead faunas. Several factors can explain these important differences. As shown by Bizon and Bizon (1985), the tests of many agglutinant taxa decompose rapidly after the death of the organisms. This phenomenon may explain the low percentages of all agglutinated taxa (including $C$. subglobosus and $K$. bradyi) in the dead faunas. The relatively low frequencies of the infaunal taxa $C$. oolina and $G$. affinis in the dead faunas may be due to the fragile character of their thin tests. However, such an explanation can not explain the very surprising near-absence of the very robust $C$. auriculus in the dead faunas, contrasting with its high relative frequency (until 19\%) in the living faunas. It may be that our sampling in March 2006 coincided with a reproductive event of this species, thus explaining the elevated densities of this taxon, which is normally relatively low frequent in comparable environments (Fontanier et al., 2003).

The relative poverty of $B$. aculeata/marginata and $B$. spathulata in the living faunas suggests that the productive periods of these taxa are not represented by our snapshot sampling in 
March 2006. It is also possible that the high relative abundance of these taxa in the dead faunas is caused by an admixture of tests originating from upper slope or outer shelf environments, due to down-slope transport. The fact that $B$. aculeata/marginata and $B$. spathulata are both high productivity taxa, which can occur in high amounts in organic-rich sediments of continental shelf sites (e.g. Jorissen, 1987; Barmawidjaja et al., 1992; Jorissen et al., 1992) strengthens this possibility.

The overall composition of the dead faunas yields some additional evidence with respect to the inferred sensitivity and/or tolerance of the dominant taxa with respect to environmental impact due to drill mud disposal. Uvigerina peregrina, apparently the most sensitive taxon, is frequent in the dead faunas of all stations, including that of station S31, $300 \mathrm{~m} \mathrm{SE}$ of the disposal site. At this station, the contrast between the poverty of $U$. peregrina in the living faunas and its elevated percentage in the dead faunas strongly suggests that this species has disappeared after the onset of drill cutting disposal. Chilostomella oolina, which shows a clear frequency increase in the living fauna of station S31, is present with percentages from 2 to $5 \%$ in the dead faunas of all stations. This suggests that $C$. oolina is strongly favoured by the environmental impact close to the disposal site, where it develops a dense population. The absence of a clear geographical trend in the dead faunas (the Renkonen index is always superior to 75) confirms that the dead faunas collected in the 2-3 depth interval are at all stations representative for the faunas which were present before the onset of drill cutting disposal, 1.5 years before sampling.

At station S31, where we investigated the composition of the dead faunas in 5 different levels between 1 and $7 \mathrm{~cm}$ depth, no significant vertical changes could be detected. Also these results confirm that the dead faunas of the $2-3 \mathrm{~cm}$ level are at all stations mainly composed of foraminifera deposited before the onset of drill mud disposal. Apparently, very few tests produced during the 1.5 years between the onset of oil exploration at the end of 2004, and our sampling in March 2006, have been added to the dead faunas at 2-3 cm depth.

\subsection{Impact of oil drill mud disposal on the foraminiferal faunas.}

From the investigated faunal parameters (density, diversity and species composition of the living and dead faunas), a clear picture arises of a significant environmental impact of drill mud disposal at station S31, 300 m SE of the disposal site. This station is characterised by an increased density and species diversity, a lower evenness, a strong density decrease of some less resistant taxa (Uvigerina peregrina, Cancris auriculus and Cribrostomoides subglobosus) and the arrival (Chilostomella oolina) or frequency increase (Reophax scorpiurus) of more tolerant species. At station S32, $500 \mathrm{~m}$ SE of the disposal site, the fauna shows some intermediate features, which could be indicative of the presence of still some environmental stress, whereas the faunas of stations S33 and S34, 1 and $2 \mathrm{~km}$ from the disposal site, respectively, appear to represent the background faunas. The faunas of station S35, where the sediment oxygen penetration appears to be less important, suggest a slightly different sedimentological context, which complicates the comparison with the faunas of the four other stations.

On the basis of the hypothesis of a maximal environmental impact at station S31, a moderate but still visible impact at station 32 and background faunas at stations S33 and S34, we can determine the most sensitive species with respect to this type of environmental impact, and also the more tolerant taxa, which are favoured by this type of phenomenon. The tendencies shown by the relative frequencies in the living faunas suggest that among the dominant taxa, Uvigerina peregrina, which shows a strongly decreased percentage at stations S31 and S32, is most sensitive to the disposal of drill mud cuttings. Cancris auriculus and Cribrostomoides subglobosus, which are still frequent at station S32, but almost absent at station S31, appear to be slightly less sensitive. Chilostomella oolina, which is absent at stations S32 to S34, but accounts for 13\% of the fauna at station S31, appears to be strongly favoured by the environmental impact. Also Reophax scorpiurus, Bolivina albatrossi, Bolivina pseudoplicata and Bulimina rostrata, that all attain maximal relative frequencies at station S31, could be favoured by drill cutting disposal. These taxa could profit 
from the reduced competitive ability of more sensitive taxa, in order to take over part of the ecological niches occupied by these taxa under natural conditions.

Uvigerina peregrina, a shallow infaunal species living close to the sediment-water interface, has been described in a wide range of mesotrophic to eutrophic continental slope settings (e.g. Lutze and Coulbourne, 1984; Corliss, 1985; Lutze, 1986; Corliss and Emerson, 1990; Corliss, 1991; Mackensen et al., 1995; Schmiedl and Mackensen, 1997; Jannink et al., 1998; Kuhnt et al., 1999; De Rijk et al., 2000 ; Schmiedl et al., 2000; Morigi et al., 2001 ; Huang et al., 2002; Fontanier et al., 2003). In the southern Angola Basin and Cape Basin, U. peregrina occurs preferentially in TOC-rich $(>1 \%)$ sediments from the upper slope, characterized by moderate (> $2 \mathrm{ml} / \mathrm{l})$ oxygen deficiency (Schmiedl et al., 1997). Licari and Mackensen (2005) suggest that the Uvigerina peregrina-dominated faunas of the upper slope in the tropical part of the eastern South Atlantic are adapted to seasonally high fluxes of marine phytodetritus, and tolerate low-quality organic matter from marine and/or terrestrial origin. U. peregrina may therefore be adapted to more degraded organic matter and lower food levels than typical high-productivity species such as Bulimina spp. and Bolivina spp. However, at a $550 \mathrm{~m}$ deep station in the Bay of Biscay, $U$. peregrina shows a particularly strong reproductive and growth response to the disposal of phytodetritus deposits, and it is less abundant during periods without an important supply of fresh organic matter (Fontanier et al., 2003; 2006). On the outer continental shelf off Congo, Mojtahid et al. (2006) find high percentages of $U$. peregrina in the dead faunas, which contrast with very low densities in the living fauna. They suggest therefore that this taxon could reproduce after periods of strong primary production in the surface waters, which may be induced by seasonal upwelling events.

Cancris auriculus, an epifaunal species, is recorded in environments characterized by seasonal upwelling leading to the combination of a high organic flux and moderate oxygen deficiency (e.g. Le Calvez, 1972; Altenbach et al., 1999, Paez et al., 2001, Diz et al., 2004).

Cribrostomoides subglobosus, a shallow infaunal species, can react rapidly to organic flux events (Linke and Lutze, 1992). It has been suggested that the occurrence of C. subglobosus indicates low but episodic fluxes of fresh organic material to the seafloor (Struck, 1995, Harloff and Mackensen, 1997).

The high abundance of these three taxa (U. peregrina, C. auriculus, C. subglobosus) typical of moderately enriched conditions in the faunas of the non-impacted stations underlines the rather eutrophic character of the natural environment, which is probably the consequence of the high surface productivity, resulting from abundant nutrient supply due to seasonal upwelling and runoff from the Congo river.

Chilostomella oolina accounts for $14 \%$ of the living assemblage ( $>150 \mu \mathrm{m}$ fraction) at station S31, whereas it is absent at stations S32, S33 and S34. C. oolina is well known from intermediate and/or deep infaunal microhabitats in eutrophic upper slope environments (e.g., Corliss, 1985, Corliss and Emerson, 1990, Van der Zwaan and Jorissen, 1991; Sen Gupta and Machain-Castillo, 1993; Bernhard and Sen Gupta, 1999 ; De Rijk et al., 2000 and Schumacher, 2001). Its life position close to the zero oxygen level shows that this species is particularly well adapted to the presence of suboxic conditions. This is confirmed by the fact that it often strongly dominates benthic foraminiferal faunas just before the onset of Mediterranean sapropels (Jorissen, 1999), which testify of prolonged periods of anoxic bottom waters. In the short periods immediately preceding the anoxic conditions, less tolerant taxa rapidly disappear, and $C$. oolina (together with some small bolivinid taxa) appears to take over the niches close to the sediment-water-interface. These observations show that $C$. oolina can as well feed on very labile food particles that are concentrated close to the sediment-water interface, as on the more refractory particles present deeper down in the sediment. The strong frequency of this taxon in the topmost level of station S31 indicates that the zero oxygen level at this station must be positioned close to the sediment surface. Its strong density increase, which coincides with the near-disappearance of Uvigerina peregrina and Cancris auriculus, suggests that at station S31, bottom water oxygenation is very low at the sediment-water interface. Apparently, the supply of hydrocarbons (adhering to the drill muds) increases the sediment oxygen demand, and as consequence, bottom water oxygen 
concentration falls below the critical threshold level for less resistant taxa such as $U$. peregrina and $C$. auriculus.

Reophax scorpiurus, Bolivina albatrossi, Bolivina pseudoplicata and Bulimina rostrata, which all show maximal frequencies at station S31, also appear to be able to tolerate this lower oxygen concentration. Fontanier et al. (2003) and Szarek et al. (2007) observe that Reophax scorpiurus is largely restricted to the shallow infaunal microhabitats in the first $\mathrm{cm}$ of the sediment. It generally occurs in environments influenced by seasonally high organic carbon fluxes (e.g., northern Gulf of Guinea) in sediments that are moderately enriched in organic carbon (e.g. Schiebel,1992; Timm,1992; Harloff and Mackensen, 1997 ; Schmiedl et al., 1997 ; Wollenburg and Mackensen, 1998 ; Kurbjeweit et al., 2000 and Ohkushi and Natori, 2001). Bolivinids, which are a dominant faunal element in the 63-150 $\mu \mathrm{m}$ fraction, are generally known for their preference for food-rich areas, and their tolerance for low-oxygen conditions (e.g. Murray, 1991; Barmawidjaja et al., 1992 ; Sen Gupta and Machain-Castillo ; 1993). They are often dominant in the oxygen-minimum zone or in upwelling zones (e.g., Phleger and Soutar, 1973; Poag, 1984; Mullins et al., 1985). Their flattened elongate morphology is considered to be an adaptation to the low-oxygen conditions (Bernhard, 1986). Bolivina albatrossi is reported from sediments with high Corg content and reduced oxygen concentrations in the Gulf of Guinea (Schiebel, 1992; Timm, 1992). Very little information is available regarding the ecological preferences of Bolivina pseudoplicata and Bulimina rostrata.

Summarizing, the analysis of the benthic foraminiferal fauna allows us to distinguish four different areas:

Station S31, located $300 \mathrm{~m}$ SE of the oil cuttings disposal site, is clearly impacted by the oil exploration activities. The benthic environment at this station experiences eutrophicated conditions; the increased organic input has probably led to a lowered oxygen concentration at the sediment-water interface. The faunas are exceptionally rich, biodiversity is maximal, but evenness shows a minimum. The deep infaunal taxon Chilostomella oolina is a dominant faunal element, and less resistant taxa such as Uvigerina peregrina and Cancris auriculus show strongly diminished densities.

Station S32, located $500 \mathrm{~m}$ SE of the oil cutting disposal site, environmental impact is weak, but still perceptible. The faunal density shows a slightly increased value in comparison to stations farther away. Uvigerina peregrina shows already a strongly lowered density.

Stations S33 and S34 are apparently no longer impacted by the drill mud disposal. Faunal density and diversity are low, and species with a low resistance to eutrophication phenomena, such as $U$. peregrina and $C$. auriculus, are present in high amounts.

Station S35, $2 \mathrm{~km} \mathrm{NW}$ of the disposal site, contains a somewhat enigmatic fauna. The presence of $C$. oolina, and the strong density maximum in the topmost half $\mathrm{cm}$ of the sediment point to a very shallow oxygen penetration into the sediment. On the contrary, $U$. peregrina and $C$. auriculus are fairly common, indicating that bottom waters were probably well oxygenated. Since both hydrocarbon and Ba-contents are low at this station, it appears that the slightly different environmental conditions at this station are not due to a contamination with drill cuttings.

Finally, we have not sampled areas closer than $300 \mathrm{~m}$ from the disposal site. It is feasible that more stressed conditions, characterised by a strongly decreased foraminiferal density, are present closer to the disposal site.

The faunal succession SE of the disposal site is remarkably similar to the foraminiferal succession described by Mojtahid et al. (2006) around 2 operating platforms on the outer continental shelf off Congo. These authors observed a first zone, at less than $100 \mathrm{~m}$ from the disposal site, which is characterised by strongly impoverished faunas. This strongly impacted area is surrounded by a second zone (from 100 to $250 \mathrm{~m}$ from the disposal site) with high density faunas enriched in some opportunistic species such as Amphicoryna scalaris, Bolivina dilatata, B. spathulata, Uvigerina peregrina, Textularia spp., Valvulineria bradyana. In a third zone (between 250 and $730 \mathrm{~m}$ from the disposal site), the environmental impact is 
minimal, but still perceptible. The difference between our data and the study of Mojtahid et al. (2006) is the absence of the most stressed area, characterised by strongly diminished faunas, in our succession. However, our most impacted station is positioned at $300 \mathrm{~m}$ from the disposal site, and the severe environmental impact described by Mojtahid et al. (2006) may therefore be present also in our study area, in the immediate vicinity of the disposal site.

The ecological characteristics of the taxa which are most tolerant to oily drill mud disposal (Chilostomella oolina, Reophax scorpiurus) suggest that the benthic foraminiferal faunas mainly respond to ecosystem eutrophication, i.e. increased food availability and reduced oxygen concentration. At present, it not clear whether the foraminiferal faunas are also impacted by the eventual presence of toxic substances, and whether foraminifera are more or less sensitive to this type of pollution than macrofauna. Comparative studies between foraminifera and macrofauna, focussing on their tolerance to pollution, are still very scarce. In a recent study, Mojtahid et al. (2008) compared the macrofaunal and foraminiferal response to organic matter pollution in the Firth of Clyde, and concluded that the sensibility of both groups is rather comparable. It is evident that more comparative studies between macrofauna and foraminifera are needed to illustrate the specific characteristics of each of these two groups of bio-indicators.

\section{Conclusions}

The benthic foraminiferal faunas found at a $670 \mathrm{~m}$ deep upper slope site off Angola show a clear response to the discharge of oily drill cuttings. The fauna at a station at $300 \mathrm{~m}$ of the disposal site is characterised by an increase of foraminiferal density and species diversity, and a decrease of evenness. The low oxygen resistant taxon Chilostomella oolina shows a strongly increased frequency, together with small-sized bolivinid and buliminid taxa. On the other hand, less resistant taxa, such as Uvigerina peregrina, Cancris auriculus and Cribrostomoides subglobosus show a strong frequency decrease. These changes point to a significant eutrophication of the ecosystem, probably accompanied by a decrease of bottom water oxygen concentration.

All stations at more than $1 \mathrm{~km}$ from the disposal site are apparently not impacted by drill mud disposal. The faunas at these stations are dominated by Karreriella bradyi, Cancris auriculus, Globobulimina affinis and Cribrostomoides subglobosus. These taxa, which are mainly living in the uppermost $\mathrm{cm}$ of the sediment, are indicative of mesotrophic to eutrophic conditions. Such mesotrophic/eutrophic conditions are logical for our upper slope area influenced by nutrient supplies from river runoff. At $500 \mathrm{~m}$ from the disposal site, the impact of drill mud disposal is still detectable, but much weaker than at the most impacted station.

Rather surprisingly, foraminifera of the large $(>150 \mu \mathrm{m})$ size fraction show a stronger response to the environmental changes brought about by oily drill mud disposal than the foraminifera of the small $(63-150 \mu \mathrm{m})$ size fraction. It appears that large-sized taxa have a much more varied response to this type of ecosystem perturbation than the often opportunistic small-sized taxa.

The investigation of the dead faunas at 2 to $3 \mathrm{~cm}$ depth in the sediment reveals that they are mainly composed of foraminifera which have been living in the area before the onset of drill mud disposal. The comparison of living and dead, pre-impact faunas has allowed us to confirm that drill mud disposal has a favourable impact on some of the more opportunistic taxa, but a strongly negative impact on the more sensitive taxa.

It appears that benthic foraminifera may provide a powerful tool to monitor the impact of anthropogenic pollution in continental slope environments. 
Altenbach, A.V., Pflaumann, U., Schiebel, R., Thies, A., Timm, S. and Trauth, M., 1999. Scaling percentages and distributional patterns of benthic foraminifera with flux rates of organic carbon. Journal of Foraminiferal Research 29, 173-185.

Alve, E., 1991. Benthic foraminifera in sediment cores reflecting heavy metal pollution in Sorfjord, Western Norway. Journal of Foraminiferal Research 21, 1-19.

Barmawidjaja, D.M., Jorissen, F.J., Puskaric, S., Van der Zwaan, G.J., 1992. Microhabitat selection by benthic foraminifera in the northern Adriatic Sea. Journal of Foraminiferal Research 22, 297-317.

Bernhard, J.M., 1996. Microaerophilic and facultative anaerobic benthic foraminifera: a review of experimental and ultrastructural evidence. Revue de Paléobiologie 15, 261-275.

Bernhard, J.M., Sen Gupta, B. K., 1999. Foraminifera of oxygen-depleted environments. In: Sen Gupta, B.K. (Ed.), Modern Foraminifera. Kluwer Academic Press, Dordrecht.

Bett, B.J., Vanreusel, A., Vincx, M., Soltwedel, T., Pfannkuche, O., Lambshead, P.J.D., Gooday, A.J., Ferrero, T. Dinet, A., 1994. Sampler bias in the quantitative study of deep-sea meiobenthos. Marine Ecology Progress series 104, 197-203.

Bizon, G., Bizon, J.J., 1985. Distribution des foraminifères sur le plateau continental du Rhône. Ecomed, 84-94.

Borja, A., Muxika, I., Franco, J., 2003. The application of a Marine Biotic Index to different impact sources affecting soft-bottom benthic communities along European coasts. Marine Pollution Bulletin 46, 835 - 845.

Braga, E.S., Andrié, C., Bourlés, B., Vangriesheim, A., Baurand, F., Chulchla, R., 2004. Congo River signature and deep circulation in the eastern Guinea Basin. Deep-Sea Research Part I 51, 1057 - 1073.

Bray, J.R., Curtis, J.T., 1957. An ordination of the upland forest communities in southern Wisconsin. Ecol. Monogr., 27, 325-349.

Breuer, E., Stevenson, A. G., Howe, J. A., Carroll, J., Shimmield ,G. B., 2004. Drill cutting accumulations in the Northern and Central North Sea: a review of environmental interactions and chemical fate. Marine Pollution Bulletin 48, 12-25.

Buckley, D.E., Owens, E.H., Schafer, C.T., Vilks, G., Cranston, R.E., Rashid, M.A., Wagner, F.J.E., Walker, D.A., 1974. Canso Strait and Chedabucto Bay: a multidisciplinary study of the impact of man on the marine environment. Geological Survey of Canada, Paper 74-30, 133160.

Busalacchi, A.J., Picaut, J., 1983. Seasonal variability from a model of the tropical Atlantic ocean. Journal of Physical Oceanography 13, 1564-1588.

Cadée, G.C., 1978. Primary production and Chlorophyll in the Zaire River, estuary and plume. Netherlands Journal of Sea Research 12, 368-381.

Cadée, G.C., 1984. Particulate and dissolved organic carbon and Chlorophyll a in the Zaire River, estuary and plume. Netherlands Journal of Sea Research 17, 426-440.

Casey, R., Amos, A., Anderson, J., Koehler, R., Schwarzer, R., Sloan, J., 1980. A preliminary report of the microplankton and microbenthon responses to the 1979 Gulf of Mexico oil spills (IXtoc I and Burmah Agate), with comments on avenues of oil to the sediments and the fate of oil in the column and on the bottom. Gulf Coast Association of Geological Societies, Transactions, 30, 273-281.

Coccioni, R., 2000. Benthic Foraminifera as Bioindicators of Heavy Metal Pollution - A case Study from the Goro lagoon (Italy). In: Martin, R.E., (Ed.), Environmental Micropaleontology, New York, 71-103.

Corliss, B.H., 1985.Microhabitats of benthic foraminifera within deep-sea sediments. Nature 314, 435-438.

Corliss, B.H., 1991. Morphology and microhabitat preferences of benthic foraminifera from the northwest Atlantic Ocean. Marine Micropaleontology 17, 195-236. 
Corliss, B.H., Emerson, S., 1990. Distribution of Rose Bengal stained deep-sea benthic foraminifera from the Nova Scotian continental margin and Gulf of Maine. Deep-Sea Research 37, 381-400.

Daan, R., Mulder, M., Vanleeuwen, A., 1994. Differential sensitivity of macrozoobenthic species to discharges of oil contaminated drill cuttings in the North Sea. Netherlands Journal of Sea Research 33, 113-127.

Davies, M., Addy, J.M., Blackman, R.A., Blanchard, J.R., Ferbrache, J.E., Moore, D.C., Somerville, H.J., Whitehead, A., Wilkinson, T., 1984. Environmental effects of the use of oilbased drilling muds in the North Sea. Marine Pollution Bulletin 15, 363-370.

De Rijk, S., Jorissen, F.J., Rohling, E.J., Troelstra, S.R., 2000. Organic flux control on bathymetric zonation of Mediterranean benthic foraminifera. Marine Micropaleontology 40, 151-166.

De Stigter, H.C., Jorissen, F.J., Van der Zwaan, G.J., 1998. Bathymetric distribution and microhabitat partitioning of live (Rose Bengal stained) benthic foraminifera along a shelf to deep-sea transect in the southern Adriatic Sea. Journal of Foraminiferal Research 12, 255272.

Denne, R.A., Sen Gupta, B.K., 1989. Effects of taphonomy and habitat on the record of benthic foraminifera in modern sediments. Palaios 4, 414-423.

Dicks, B., Bakke, T., Dixon , I.M.T., 1988. Oil exploration and production and oil spills. In: W. Salomons, B.L. Bayne, E.K. Duursma and U. Förstner, Editors, Pollution of the North Sea: an assessment, Springer-Verlag, Berlin, pp. 524-537.

Diz, P., Francés, G., Costas, S., Souto C., Alejo, I., 2004. Distribution of benthic foraminifera in coarse sediments, Ria de Vigo, NW Iberian Margin. Journal of Foraminiferal Research 34, 258-275.

Duchemin, G., Fontanier, C., Jorissen, F.J., Barras, C., Griveaud, C., 2007. Living smallsized $(63-150 \mu \mathrm{m})$ foraminifera from mid-shelf to mid-slope environments in the Bay of Biscay. Journal of Foraminiferal Research 37, 12-32.

Durrieu, J., Bouzet, P., 2004. Seabed recolonization : N'Kossa case, vol. 86710. Society of Petroleum Inc. SPE, Calgary. 8 pp.

Durrieu, J, Mojtahid, M., Cazes, L., Galgani, F., Jorissen, F., Tran, D., Camps, R., 2006. Aged drilled cuttings offshore Gabon : new methodology for assessing their impact. Society of Petroleum Engineers Inc. SPE, vol. 98414, 8 pp.

Ernst, S.R., Morvan, J., Geslin, E., Le Bihan, A.. Jorissen ,F.J, 2006. Benthic foraminiferal response to experimentally induced Erika oil pollution. Marine Micropaleontology 61, 76-93.

Flaten, G. R., Botnen, H., Grung, B., Kvalheim, O. M., 2007. Quantifying disturbance in benthic communities-comparison of the community disturbance index (CDI) to other multivariate methods. Ecological Indicators 7, 254 -276.

Fontanier, C., Jorissen, F., Anschutz, P., Chaillou, G., 2006. Seasonal variability of benthic foraminiferal faunas at $1000 \mathrm{~m}$ depth in the Bay of Biscay. Journal of Foraminiferal Research 36, 61-76.

Fontanier, C., Jorissen, F. J., Chaillou, G., David, C., Anschutz, P., Lafon, V., 2003. Seasonal and interannual variability of benthic foraminiferal faunas at $550 \mathrm{~m}$ depth in the Bay of Biscay. Deep-Sea Research Part I 50, 457-494.

Fontanier, C., Jorissen, F. J., Licari, L. , Alexandre, A., Anschutz, P., Carbonel, P., 2002. Live benthic foraminiferal faunas from the Bay of Biscay: faunal density, composition, and microhabitats. Deep-Sea Research Part I 49, 751-785.

Gage, J.D., 2001. Deep-sea benthic community and environmental impact assessment at the Atlantic Frontier. Continental Shelf Research 21, 357-986.

Gass, S.E., and Roberts J. M., 2006. The occurrence of the cold-water coral Lophelia pertusa (Scleractinia) on oil and gas platforms in the North Sea: Colony growth, recruitment and environmental controls on distribution. Marine Pollution Bulletin 52, 549-559.

Geslin, E., Debenay, J.-P., Duleba, W., Bonetti, C., 2002. Morphological abnormalities of foraminiferal tests in Brazilian environments: comparison between polluted and non-polluted areas. Marine Micropaleontology 45, 151-168. 
Geslin, E., Stouff, V., Debenay, J.-P., Lesourd, M., 2000. Environmental variation and foraminiferal test abnormalities. In: Martin, R.E. (Ed.). Environmental Micropaleontology. The Application of microfossils to Environmental Geology. New York, Kluwer, 191-215.

Giraudeau, J., Christensen, B.A., Hermelin, J.O.R., Lange, C.B., Motoyama, I., Wefer, G., Berger, W.H., Richter, C., Adams, D.D., Anderson, L.D., Andreasen, D.J., Bruchert, V., Cambray, H., Frost, G.M., Gorgas, T.J., Jansen, J.H.F., Laser, B., Lin, H.L., Maslin, M., Meyers, P.A., Murray, R.W., Perez, M.E., Pufahl, P.K., Spiess, V., Vidal, L., Wingley, R., Yamazaki, T., 1998. Biostratigraphic age models and sedimentation rates along the southwest African margin. In: Wefer, G., Berger, W.H., Richter, C. (Eds.), Proceedings of the ocean Drilling Program. Initial Reports, 543-546.

Grant, A., Briggs, A., 2002. Toxicity of sediments from around a North Sea oil platform: are metals of hydrocarbons responsible for ecological impacts? Marine Environmental Research 53, 95-116.

Gray, J.S., Clarke, K.R., Warwick R.M., Hobbs , G., 1990. Detection of initial effects of pollution on marine benthos-an example from the Ekofisk and Eldfisk oilfields, North Sea. Marine Ecology Program Series 66, 285-299.

Hardman-Mountford, N.J., Richardson , A.J., Agenbag , J.J., Hagen, E., Nykjaer , L., Shillington , F.A., Villacastin, C., 2003. Ocean climate of the South East Atlantic observed from satellite data and wind models. Progress in Oceanography 59, 181-221.

Harloff, J., Mackensen, A.,1997. Recent benthic foraminiferal associations and ecology of the Scotia Sea and Argentine Basin. Marine Micropaleontology 31, 1-29.

Hayek, L.A.C., Buzas, M. A., 1997. Surveying Natural Populations. New York, Columbia.

Huang, B., Jian, Z., Cheng, X., Wang, P., 2002. Foraminiferal responses to upwelling variations in the South China Sea over the last 22000 years. Marine Micropaleontology 47, 115.

Jannink, N.T., Zachariasse, W.J., Van der Zwaan, G.J., 1998. Living (Rose Bengal stained) benthic foraminifera from the Pakistan continental margin (northern Arabian Sea). Deep-Sea Research Part I 45, 1483-1513.

Jorissen, F.J., 1987. The distribution of benthic foraminifera in the Adriatic Sea. Marine Micropaleontology 12, 21-48.

Jorissen, F.J., 1999. Benthic foraminiferal microhabitats. In : Sen Gupta, B.K. (Ed.), Ecology of recent Foraminifera. Kluwer Academic Publishers, Dordrecht, pp. 161-179.

Jorissen, F.J. and Wittling, I., 1999. Ecological evidence from live-dead comparisons of benthic foraminiferal faunas off Cape Blanc (Northwest Africa). Palaeogeography, Palaeoclimatology, Palaeoecology 149, 151-170.

Jorissen, F.J., Buzas, M.A., Culver, S.J., Kuehl, S.A.,1992. Vertical distribution of living benthic foraminifera in submarine canyons off New Jersey. Journal of Foraminiferal Research 24, 28-36.

Jorissen, F.J., De Stigter, H.C., Widmark, J.G.V, 1995. A conceptual model explaining benthic foraminiferal microhabitats. Marine Micropaleontology 26, 3-15.

Jorissen, F. J., Fontanier, C., Thomas, E., 2007. Chapter Seven Paleoceanographical Proxies Based on Deep-Sea Benthic Foraminiferal Assemblage Characteristics. Developments in Marine Geology 1, 263-325.

Jorissen, F.J., Wittling, I., Peypouquet, J.P., Rabouille, C., Relexans, J.C., 1998. Live benthic foraminiferal faunas off Cape Blanc, NW Africa; community structure and microhabitats. Deep-Sea Research I 45, 2157-2188.

Krebs, C.J., 1998. Ecological methodology. Second Edition. Addison Wesley Longman Eds. $620 \mathrm{pp}$.

Kuhnt, W., Hess, S., Jian, Z., 1999. Quantitative composition of benthic foraminiferal assemblages as a proxy indicator for organic carbon flux rates in the South China Sea. Marine Geology 156, 123-157.

Kurbjeweit, F., Schmiedl, G., Schiebel, R., Hemleben, C., Pfannkuche, O., Wallmann, K., Schafer, P., 2000. Distribution, biomass and diversity of benthic foraminifera in relation to sediment geochemistry in the Arabian Sea. Deep-Sea Research Part II 47, 2917-2955. 
Lagoon (Italy). In: Martin R.E. (Ed.), Environmental Micropaleontology, New York, 71103.

Le Calvez, Y., 1972. Etude écologique de quelques foraminifères de la cote saharienne de l'Atlantique. Revue Travaux Institut Peches Maritimes 36, 245-254.

Licari, L., Mackensen, A., 2005. Benthic foraminifera off West Africa ( $1^{\circ} \mathrm{N}$ to $\left.32^{\circ} \mathrm{S}\right)$ : do live assemblages from the topmost sediment reliably record environmental variability? Marine Micropaleontology 55, 205-233.

Linke, P., Lutze, G.F., 1992. Microhabitat preferences of benthic foraminifera. A static concept or a dynamic adaptation to optimize food acquisition. Marine Micropaleontology 20, 215-234.

Locklin, J.A. and Maddocks, R.F., 1982. Recent foraminifera around petroleum production platforms on the southwest Louisiana shelf. Gulf Coast Association of Geological Societies Transaction, 32, 377-397.

Loubere, P., 1989. Bioturbation and sedimentation rate control of benthic microfossil taxon abundances in surface sediments: a theoretical approach to the analysis of species microhabitats. Marine Micropaleontology 14, 317-325.

Lutjeharms, J.R.E., Meeuwis, J.M., 1987. The extend and variations of south-east Atlantic upwelling. In : Payne, A.I.L., Gulland, J.A., Brink, K.H., (Eds.), The Benguela and Comparable Ecosystems. South African Journal of Marine Science 5, 35-49.

Lutze, G.F., 1986. Uvigerina species of the eastern North Atlantic. In : Van der Zwaan, G.J., Jorissen, F.J., Verhallen, P.J.J.M., von Daniels, C.H. (Eds.), Atlantic -European Oligocene to Recent Uvigerina. Utrecht Micropaleontological Bulletins 35, 21-46.

Lutze, G.F. and Coulbourn, W.T., 1984. Recent benthic foraminifera from the continental margin of northwest Africa: community structure and distribution. Marine Micropaleontology 8, 361-401.

Mackensen, A., Schmiedl, G., Harloff , J., Giese, M., 1995. Deep-sea foraminifera in the South Atlantic Ocean: ecology and assemblage generation. Micropaleontology 41, 342-358.

Martin, R.E., 2000. Environmental Micropaleontology. The Application of microfossils to Environmental Geology. New York, Kluwer.

Mojtahid, M., Jorissen, F., Durrieu, J., Galgani, F., Howa, H., Redois, F., Camps, R., 2006. Benthic foraminifera as bio-indicators of drill cutting disposal in tropical east Atlantic outer shelf environments. Marine Micropaleontology 61, 58 -75.

Mojtahid, M., Jorissen, F.J., Pearson, T.H., 2008. Comparison of benthic foraminiferal and macrofaunal responses to organic pollution in the Firth of Clyde (Scotland). Marine Pollution Bulletin, 56, 42-76.

Morigi, C., Jorissen, F.J., Gervais, A., Guichard, S., Borsetti, A.M., 2001. Benthic foraminiferal faunas in surface sediments off NW Africa: relationship with the organic flux to the ocean floor. Journal of Foraminiferal Research 31, 350-368.

Mullins, H.T., Thompson, J.B., McDougall, K., Vercoutere, T.L., 1985. Oxygen-minimum zone edge effects: evidence from the central California coastal upwelling system. Geology 13, 491-494.

Murray, J.W., 1991. Ecology and distribution. Benthos 90. Tokai University Press, Sendai.

Murray, J.W., 2001. The niche of benthic foraminifera, critical thresholds and proxies. Marine micropaleontology 41, 1-7.

Murray, J.W., 2007. Biodiversity of living benthic foraminifera: How many species are there? Marine Micropaleontology 64, 163-176.

Muxika, I., Borja, A., Bonne, W., 2005. The suitability of the marine biotic index (AMBI) to new impact sources along European coasts. Ecological Indicators 5, 19 -31.

Ohkushi, K., Natori, H., 2001. Living benthic foraminifera of the Hess Rise and Suiko Seamount, central North Pacific. Deep-Sea Research Part I 48, 1309-1324.

Olsen, G.H., Sva, E., Carroll, J.L., Camus, L., De Coen, W., Smolders, R., Øveraas, H., Ketil Hyllan, K., 2007. Alterations in the energy budget of Arctic benthic species exposed to oilrelated compounds. Aquatic Toxicology 83, 85-92. 
Olsgard, F., Gray, J. S., 1995. A comprehensive analysis of the effects of offshore oil and gas exploration and production on the benthic communities of the Norwegian continental shelf. Marine Ecological Progress Series, 122, 277 -306.

O'Malley, R, 2007. Research activities at Oregon State University, WWW Page, http://web.science.oregonstate.edu/ocean.productivity/index.php

Dalmazzone, Ch., Blanchet, D., Lamoureux, S., Dutrieux, E., Durrieu, J., Camps, R., Galgani, F., 2004. Impact of drilling activities in warm sea: recolonization capacities of seabed. Oil \& Gas Science and Technology - Rev. IFP 59, 625- 647.

Paez, M., Zuniga, O., Valdés, J., Ortlieb, L., 2001. Foraminiferos bentonicos recientes en sedimentos microxicos de la bahia Mejillones del Sur $\left(23^{\circ}\right)$, Chile. Revista de Biologia y Oceanografia 36 (2), 129-139.

Pearson, T.H., Rosenberg, R., 1978. Macrobenthic succession in relation to organic enrichment and pollution of the marine environment. Oceanography and Marine Biology Annual Review 16, 229-311.

Phleger, F.B., Soutar, A., 1973. production of benthic foraminifera in three east Pacific oxygen minima. Micropaleontology 19, 110-115.

Poag, C. W., 1984. Distribution and ecology of deep-water benthic foraminifera in the Gulf of Mexico. Palaeogeography, Palaeoclimatology, Palaeoecology 48, 25-37.

Renkonen, O., 1938. Statistisch-ökologische Untersuchungen über die terrestische Käferwelt der finnischen Bruchmoore. An. Zool. Soc. Zool-Bot. Fenn. Vanamo 6, 1-231.

Risgaard-Petersen, N., Langezaal, A.M., Ingvardsen, S., Schmid, M.C., Jetten, M.S.M., op den Camp, H.J.M., Derkensen, J.W.M., Pina-Ochoa, E., Eriksson, S.P., Nielsen, L.P., Revsbech, N.P., Cedhagen, T., Van der Zwaan, G.J., 2006. Evidence for complete denitrification in a benthic foraminifer. Nature 443, 93-96.

Sanders, H.L., 1960. Benthic studies in Buzzards Bay III. The structure of the soft-bottom community. Limnology and Oceanography 5, 138-153.

Schiebel, R., 1992. Rezente benthische Foraminiferen in Sedimenten des Schelfes und oberen Kontintalhanges im Golf von Guinea (Westafrika). Berichte-Reports, GeologischPalaontologisches Institut und Museum Christian-Albrechts-Universität Kiel 51, 126.

Schmiedl, G. and Mackensen, A., 1997. Late Quaternary paleoproductivity and deep water circulation in the eastern South Atlantic Ocean: evidence from benthic foraminifera. Palaeogeography, Palaeoclimatology, Palaeoecology 130, 43-80.

Schmiedl, G., De Bovée, F., Buscail, R., Charrière, B., Hemleben, C., Medernach, L., Picon, P., 2000. Trophic control of benthic foraminiferal abundances and microhabitat in the bathyal Gulf of Lions, western Mediterranean Sea. Marine Micropaleontology 40, 167-188.

Schmiedl, G., Mackensen, A., Muller P.J., 1997. Recent benthic foraminifera from the eastern South Atlantic Ocean: Dependence on food supply and water masses. Marine Micropaleontology 32, 249 - 287.

Schneider, R.R., Price, B., Müller, P.J., Kroon, D., Alexander, I., 1997. Monsoon related variations in Zaire (Congo) sediment load and influence of fluvial silicate supply on marine productivity in the east equatorial Atlantic during the last 200,000 years. Paleoceanography $12,463-481$

Schumacher, S., 2001. Mikrohabitatanspruche bentischer Foraminiferen in Sedimenten des Sudatlantiks. Berichte zur Polarforschung 403, 151.

Sen Gupta, B.K., Machain-Castillo, M.L., 1993. Benthic foraminifera in oxygen-poor habitats. Marine Micropaleontology 20, 3-4.

Shannon, L.V., Pillar, S.C., 1986. The Benguela Ecosystem Part III. Plankton. Oceanography Marine Biology Annual Review 24, 65-170.

Sharifi, A.R., Croupade, I.W., Austin, R.L., 1991. Benthic foraminiferids as pollution indicators in Southampton Water, Southern England. Journal of Micropaleontology 10, 109-130

Shimmield, G.B., Breuer, E., Cummings, D.G., Pepper, O., Shimmield, T., 2000. Contaminant leaching from drilling cuttings piles of the northern and central North Sea: field results from Beryl "A" cuttings pile. Scottish Association for Marine Science, 28 pp.

Struck, U., 1995. Stepwise postglacial migration of benthic foraminifera into the abyssal north-eastern Norwegian Sea. Marine Micropaleontology 26 , 207-2 13. 
Stubbles, S.J., Hart, M., Williams, C. and Green, J., 1996. Responses of foraminifera to presence of heavy metal contamination and acidic mine drainage. The Institution of Mining and Metallurgy, 217-235.

Sutherland, T.F., Livings, C.D., Petersen, S.A., Poona, P., Pierce, B., 2007. The use of meiofauna as an indicator of benthic organic enrichment associated with salmonid aquaculture. Marine Pollution Bulletin 54, 1249-1261.

Szarek, R., Nomaki, H., Kitazato, H., 2007. Living deep-sea benthic foraminifera from the warm and oxygen-depleted environment of the Sulu Sea. Deep Sea Research Part II 54, 145-176.

Timm, S., 1992. Rezente Tiefsee-Benthosforaminiferen aus Oberflachen-sedimenten des Golfes von Guinea (Westafrika)- Taxonomie, Verbreitung, Ökologie und Korngrossenfraktionene. Berichte-Reports Geologisch-Palaontologisches Institut und Museum Christian-Albrechts-Universität Kiel 59, 155.

Uliana, E., Lange, C. B., Wefer, G., 2002. Evidence for Congo River freshwater load in Late Quaternary sediments of ODP Site $1077\left(5^{\circ} \mathrm{S}, 10^{\circ} \mathrm{E}\right)$. Palaeogeography, Palaeoclimatology, Palaeoecology 187, 137-150.

Van Bennekom, A.J., Berger, G.W., 1984. Hydrography and silica budget of the Angola Basin. Netherlands Journal Sea Research 17, 149-200.

Van der Zwaan, G.J., Jorissen, F.J., 1991. Biofacial patterns in river-induced shelf anoxia. In: Tyson, R.V., Pearson, T.H. (Eds.), Modern and Ancient Continental Shelf Anoxia, Geological Society, Special publication, 58, 65-82.

Vénec-Peyré, M.T., 1981. Les foraminifères et la pollution: étude de la microfaune de la cale du Dourduff (embouchure de la rivière de Morlaix). Cahiers de Biologie Marine, 22, 25-33.

Verstraete, J.M., 1985. Contre-courants équatoriaux et variations saisonnières du contenu thermique et du niveau moyen dans l'Atlantique tropical Est. Oceanologica Acta 8, 249-261.

Wenzhöfer, F., Guld, R.N., 2002. Benthic carbon mineralization in the Atlantic: a synthesis based on in situ data from the last decade. Deep-Sea Research I 49, 1255-1279.

Wollenburg, J.E., Mackensen, A., 1998. Living benthic foraminifers from the central Arctic Ocean: faunal composition, standing stock and diversity. Marine Micropaleontology 34, 153185.

\section{Figures}




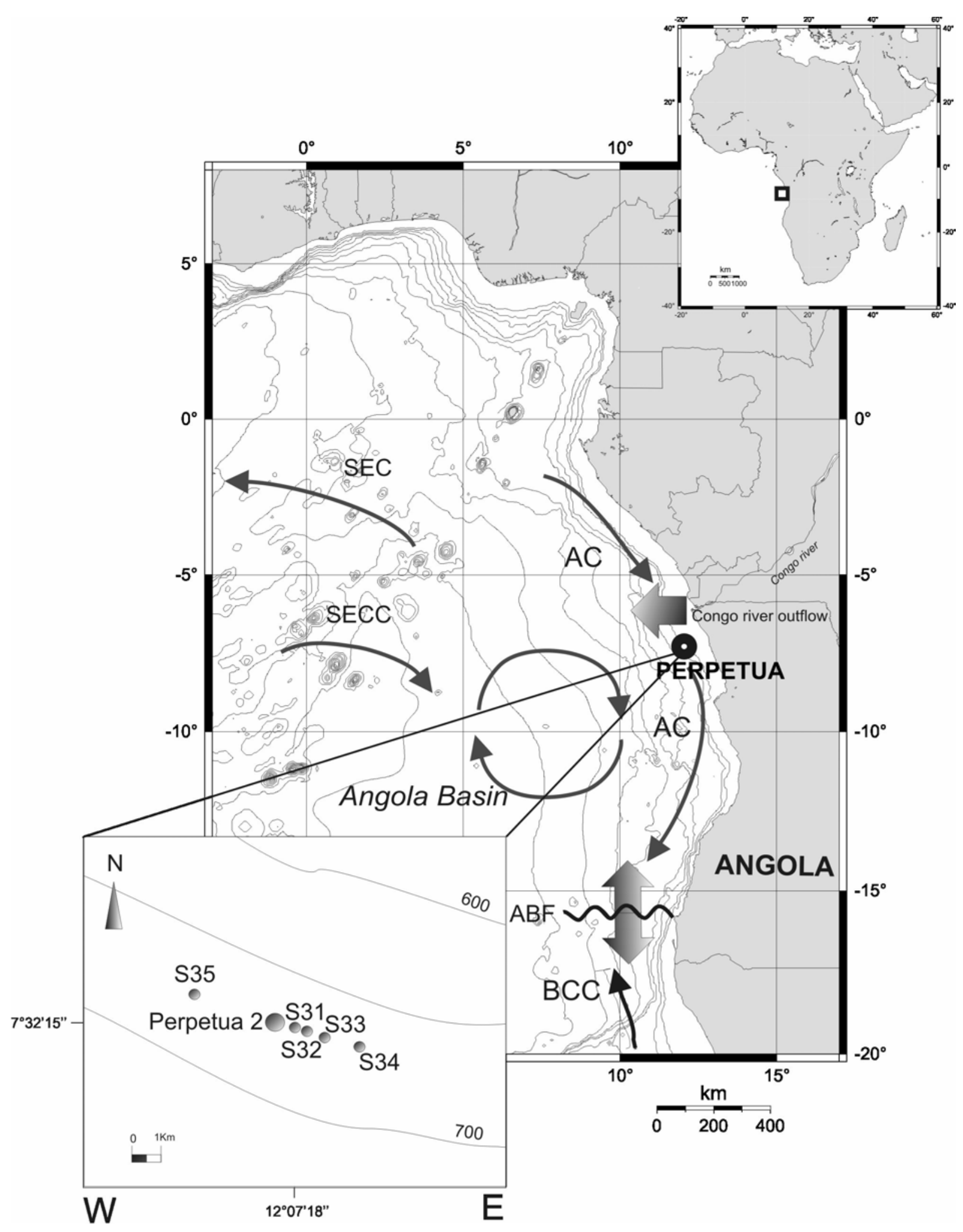

Fig. 1. Geographical position, bathymetry and main hydrographic features of the study area. AC: Angola Current; SEC: Southern Equatorial Current; SECC: Southern Equatorial Counter Current; BCC: Benguela Coastal Current. ABF: Angola-Benguela Front. Modified after Licari and Mackensen, 2005. 
Fig. 2
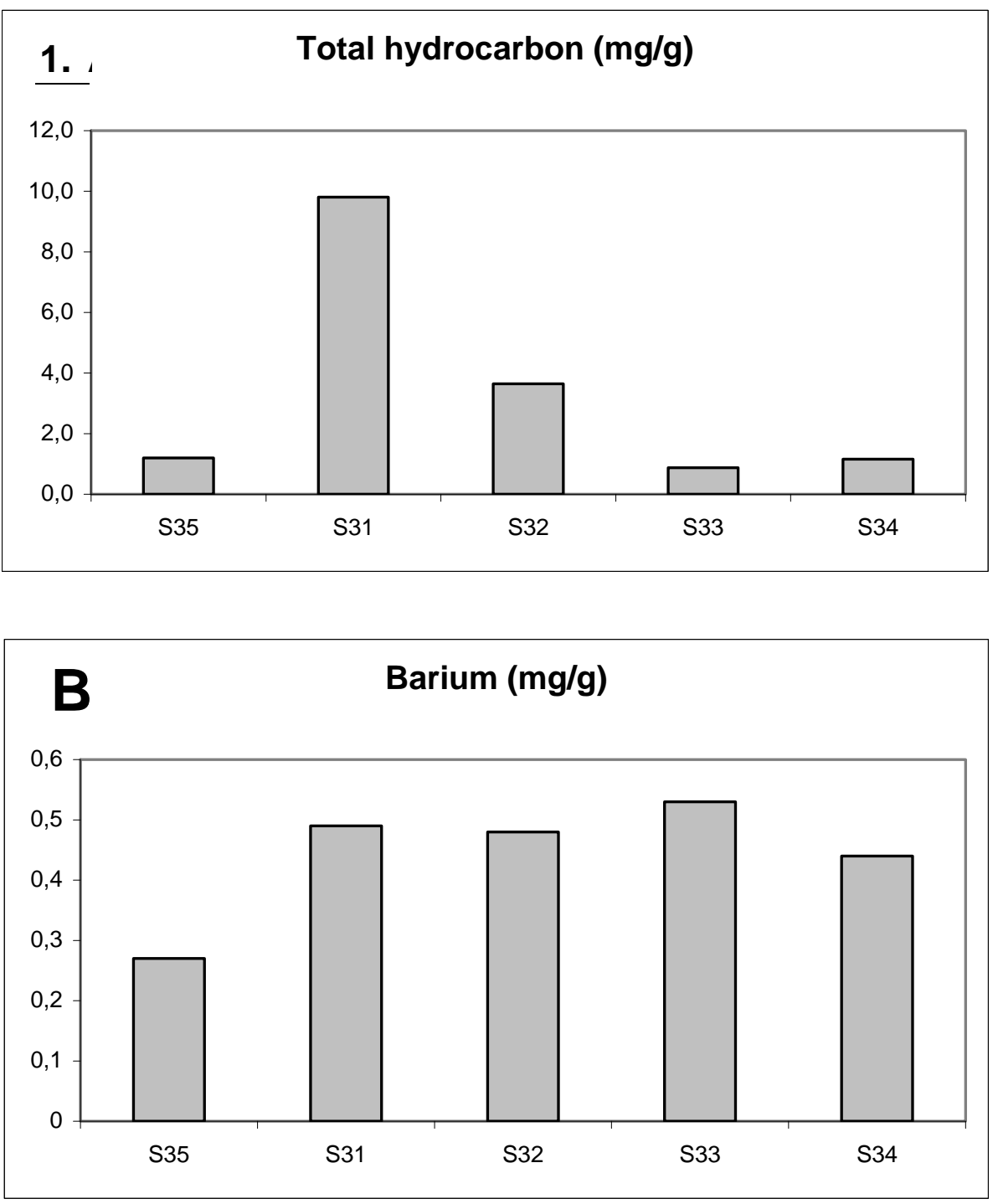

Fig. 2. Concentrations of total hydrocarbon and barium (both in $\mathrm{mg} / \mathrm{g}$ dry weight) at the five sampling stations. 

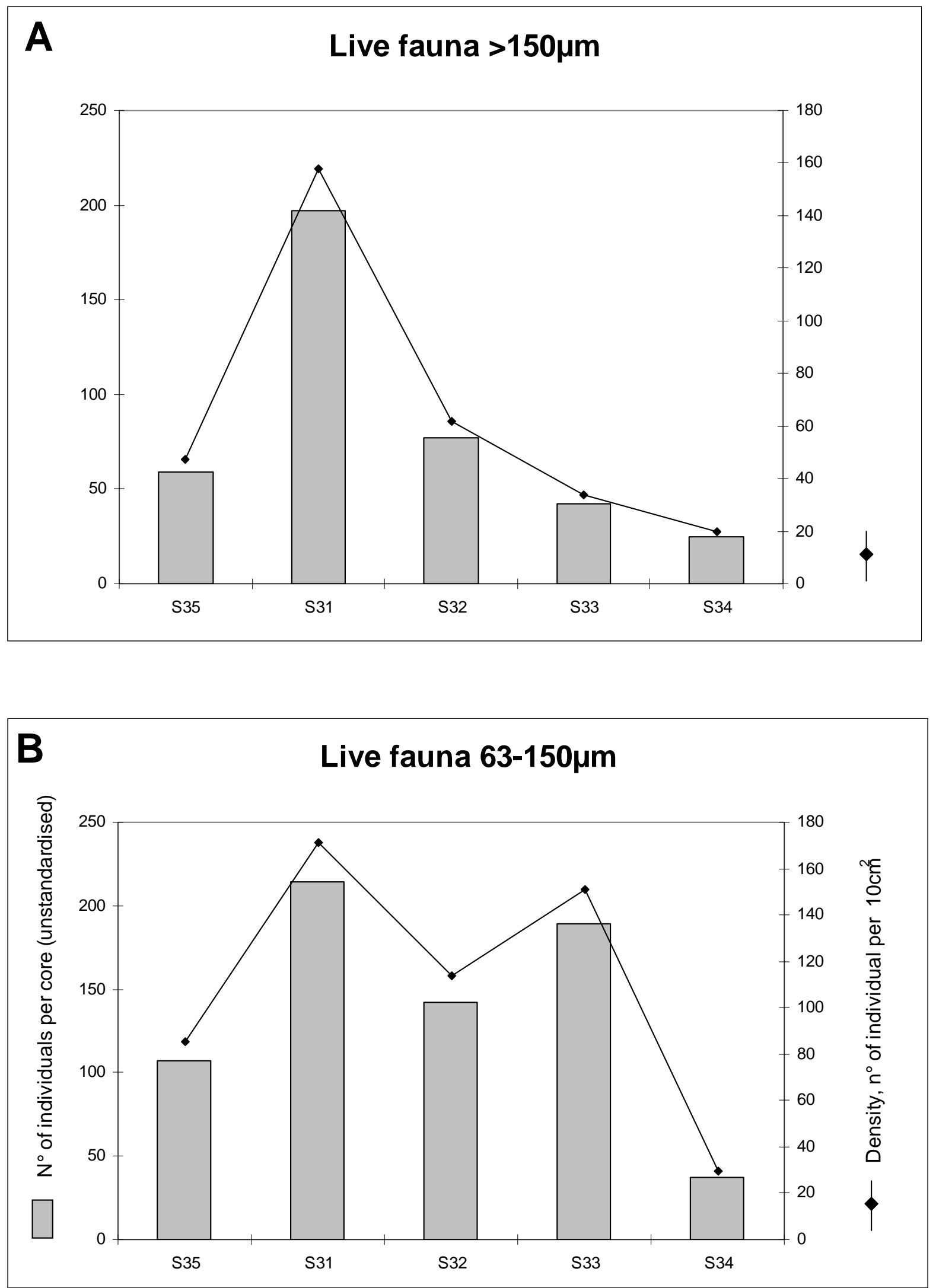

Fig. 3. Total number of living individuals at each station (non standardised) from 0 to $3 \mathrm{~cm}$ depth (scale at the left) and foraminiferal density, standardised for a surface area of $10 \mathrm{~cm}^{2}$ (scale at the right). Fig 3A: $>150 \mu \mathrm{m}$ fraction. Fig 3B: 63-150 $\mu \mathrm{m}$ fraction. 


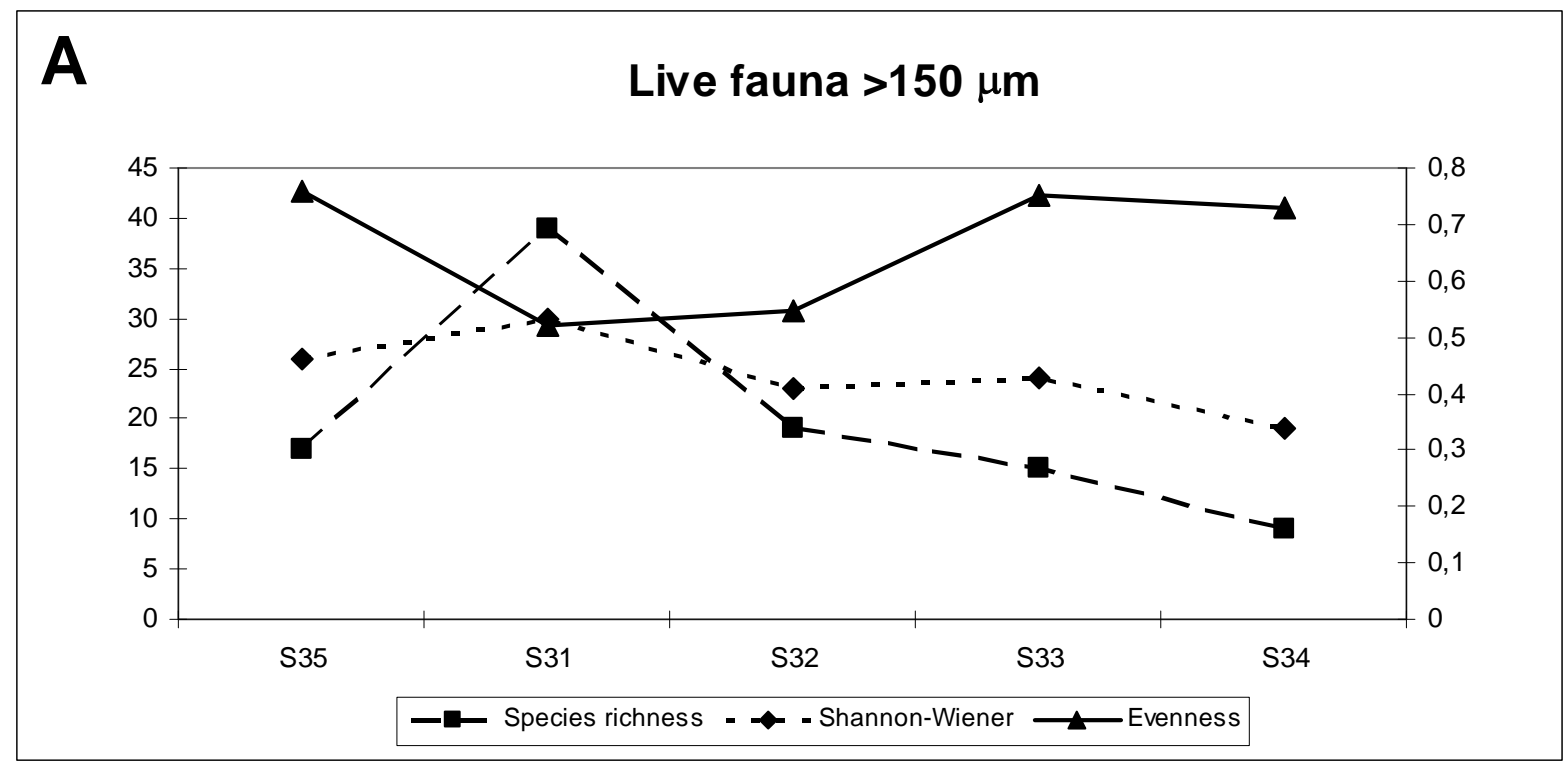

B Live fauna 63-150 $\mu \mathrm{m}$

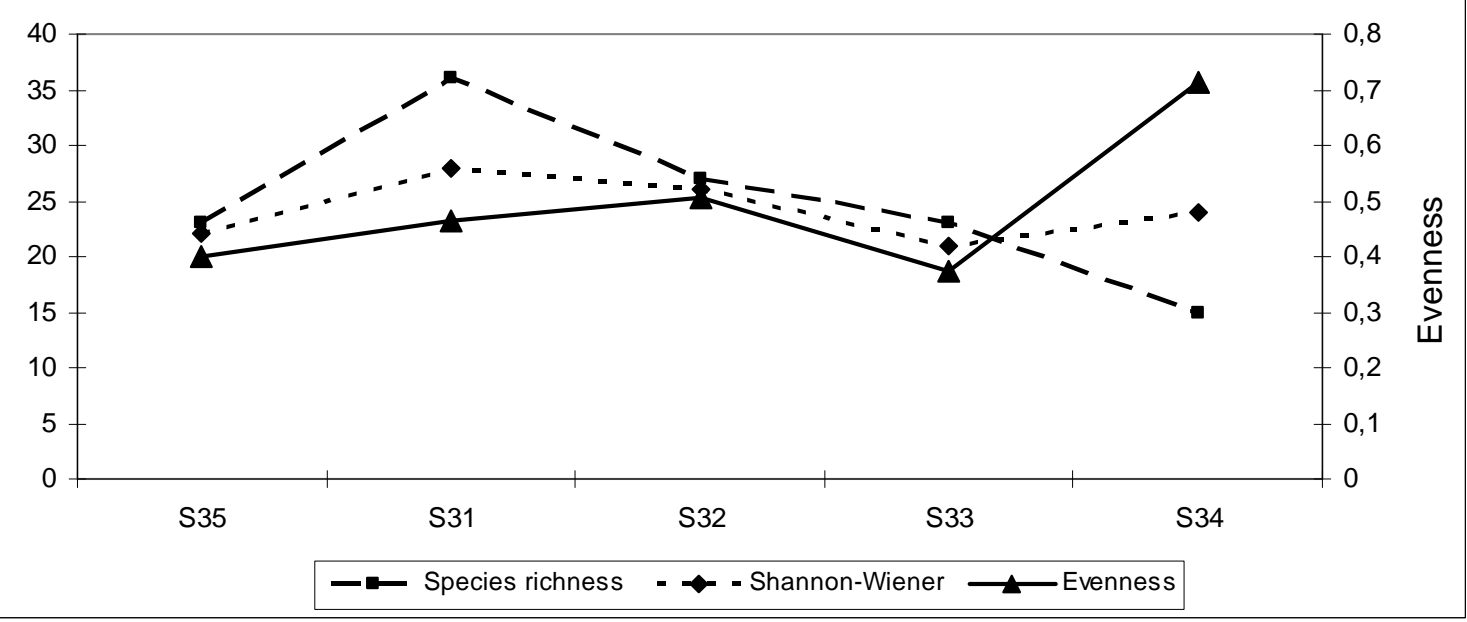

Fig. 4. Species richness $(\mathrm{S})$, Shannon-Wiener index $(\mathrm{H})$ and evenness at the five sampling stations. Fig. 4A: $>150 \mu \mathrm{m}$ fraction. Fig. 4B: 63-150 $\mu \mathrm{m}$ fraction. 

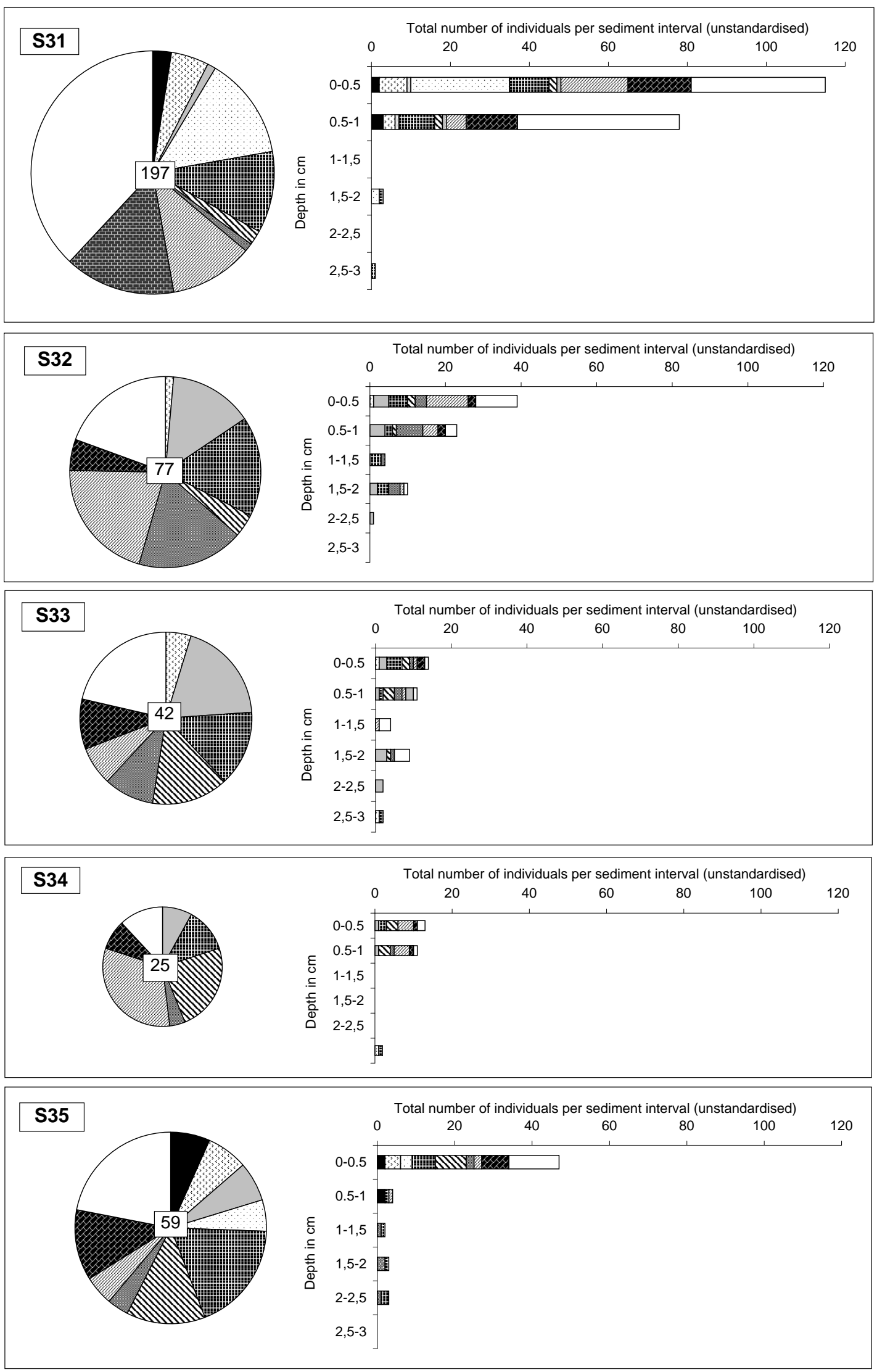

Bolivina albatrossi

Bulimina marginata

Cancris auriculus

Chilostomella oolina

Globobulimina affinis
Uvigerina peregrina

Cribrostromoides subglobosus

Karreriella bradyi

Reophax scorpiurus

Others 
Fig. 5. Composition of the foraminiferal faunas (left side) and vertical distribution (right side) in the topmost $3 \mathrm{~cm}$ of the sediment at the 5 sampling stations, $>150 \mu \mathrm{m}$ fraction. For each station, the total number of individuals (non standardised) is indicated in the centre of the pie diagrams. 


\section{$63-150 \mu \mathrm{m}$ fraction}
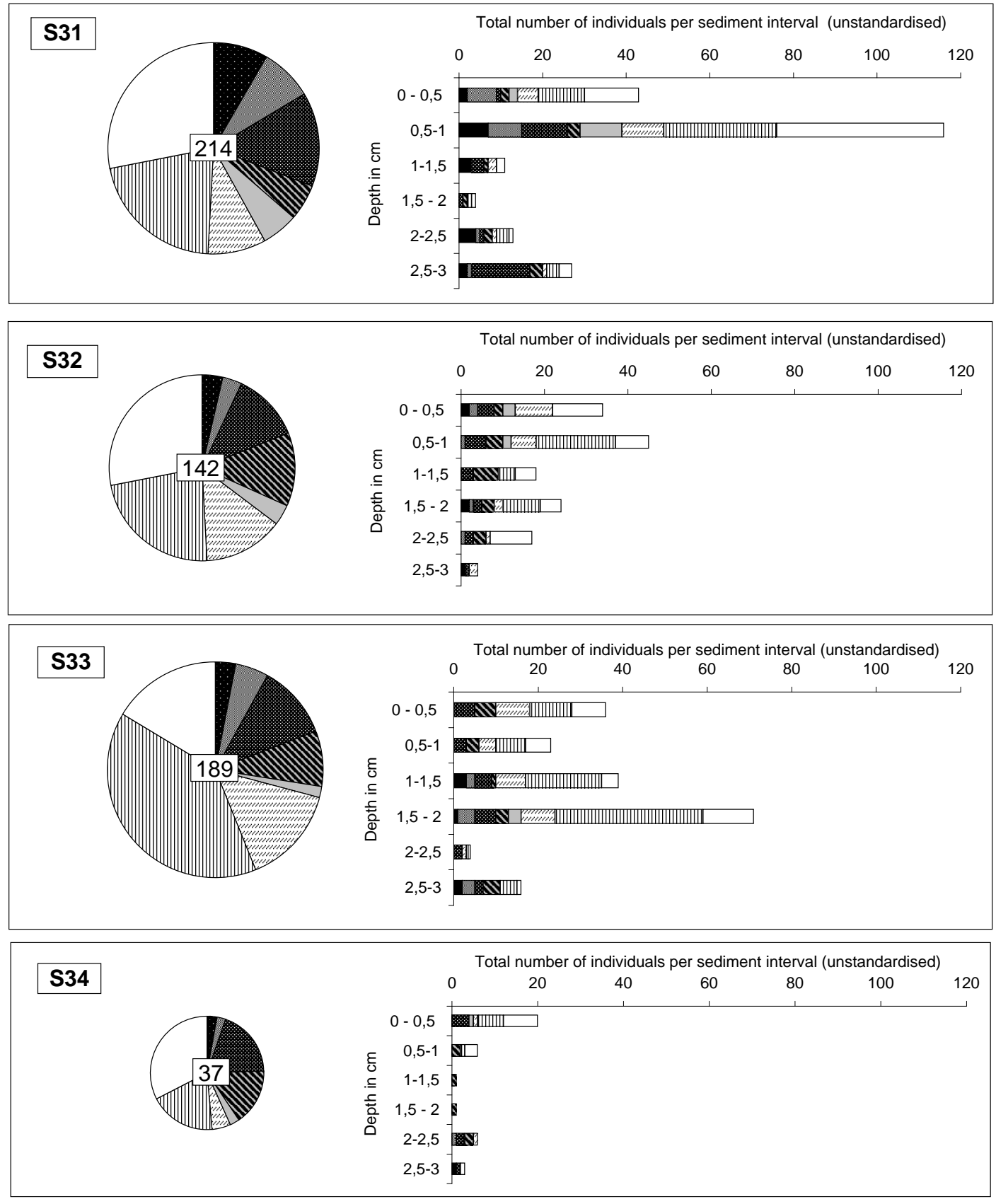

S35
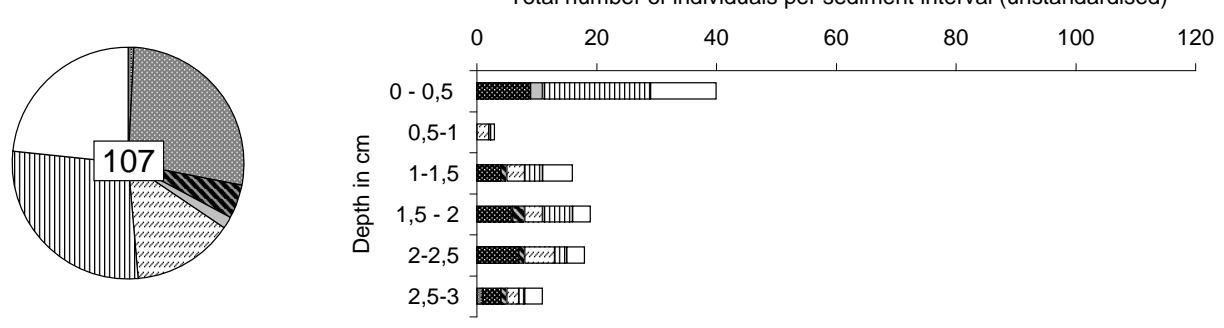

Bolivina albatrossi

Nuttallides pusillus

Bulimina rostrata

Bolivina spathulata

Bolivina pseudoplicata

Brizalina earlandi

Gyroidinoides orbicularis

Others 
Fig. 6. Composition of the foraminiferal faunas (left side) and vertical distribution (right side) in the topmost $3 \mathrm{~cm}$ of the sediment at the 5 sampling stations, $63-150 \mu \mathrm{m}$ fraction. For each station, the total number of individuals (non standardised) is indicated in the centre of the pie diagrams. 

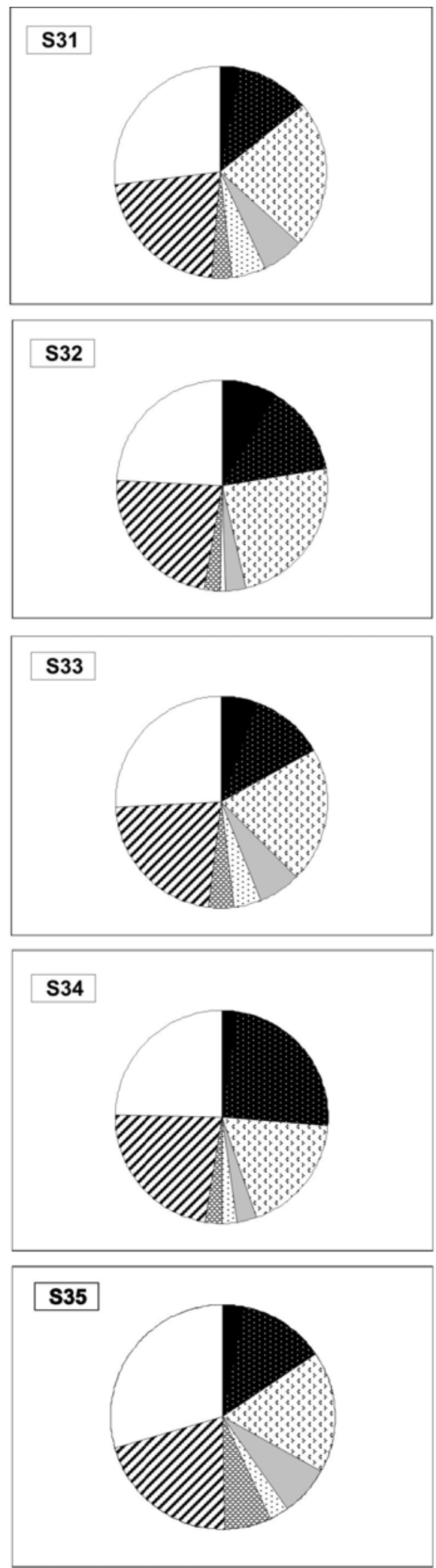

Bolivina albatrossi

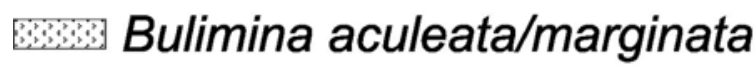
Chilostomella oolina VIII Uvigerina peregrina
Bolivina spathulata Bulimina inflata/costata Globobulimina affinis Others 
Fig. 7. Distribution of the main species of the dead foraminiferal fauna (percentages distribution) in the $2-3 \mathrm{~cm}$ level of the 5 sampling stations, $>150 \mu \mathrm{m}$ fraction.

\section{Tables}

\begin{tabular}{|c|c|c|c|c|}
\hline Station & Distance from platform & Latitude & Longitude & Water depth $(\mathrm{m})$ \\
\hline S31 & $300 \mathrm{~m}$ & $7^{\circ} 32^{\prime} 15.1966^{\prime \prime} \mathrm{S}$ & $12^{\circ} 07^{\prime} 18.758^{\prime \prime} \mathrm{E}$ & 670 \\
\hline S32 & $500 \mathrm{~m}$ & $7^{\circ} 32^{\prime} 17.057^{\prime \prime} \mathrm{S}$ & $12^{\circ} 07^{\prime} 24.540 " \mathrm{E}$ & 670 \\
\hline S33 & $1 \mathrm{~km}$ & $7^{\circ} 32^{\prime} 21.898^{\prime \prime} \mathrm{S}$ & $12^{\circ} 07^{\prime} 40.5611^{\prime \prime} \mathrm{E}$ & 670 \\
\hline S34 & $1.8 \mathrm{~km}$ & $7^{\circ} 32^{\prime} 29.557^{\prime \prime} \mathrm{S}$ & $12^{\circ} 08^{\prime} 05.479^{\prime \prime} \mathrm{E}$ & 670 \\
\hline S35 & $2 \mathrm{~km} \mathrm{~W}$ & $7^{\circ} 31^{\prime} 53.1699^{\prime \prime} \mathrm{S}$ & $12^{\circ} 06^{\prime} 07.122^{\prime \prime} \mathrm{E}$ & 670 \\
\hline
\end{tabular}

Table 1

\begin{tabular}{|c|c|c|c|}
\hline Station & Total Hydrocarbons $(\mathrm{mg} / \mathrm{g})$ & $\begin{array}{c}\text { Total labile fraction } \\
\text { of hydrocarbons }\left(\mu \mathrm{g} \mathrm{g}^{-1}\right)\end{array}$ & Barium $(\mathrm{mg} / \mathrm{g})$ \\
\hline S31 & 9.808 & 93,9 & 0.49 \\
\hline S32 & 3.647 & 37,78 & 0.48 \\
\hline S33 & 0.875 & 13,22 & 0.53 \\
\hline S34 & 1.158 & 13,59 & 0.44 \\
\hline S35 & 1.199 & 21,09 & 0.27 \\
\hline
\end{tabular}

Table 2

Table 1. Geographical position, water depth and distance from the platform of the five sampling stations

Table 2. Concentrations of total hydrocarbons, the labile fraction of hydrocarbons ( $\mathrm{nC} 13$, nC15, nC16, nC17, nC19, nC20), and barium in the superficial sediment at the five sampling stations.

\begin{tabular}{|c|c|c|c|c|c|}
\hline$>150 \mu \mathrm{m}$ living & S31 & S32 & S33 & S34 & S35 \\
\hline S31 & & & & & \\
\hline S32 & 39.6 & & & & \\
\hline S33 & 25.4 & 61.9 & & & \\
\hline S34 & 35.8 & 57.8 & 53.4 & & \\
\hline S35 & 53.0 & 43.8 & 60.8 & 44.8 & \\
\hline $63-150 \mu \mathrm{m}$ living & S31 & S32 & S33 & S34 & S35 \\
\hline S31 & & & & & \\
\hline S32 & 69.2 & & & & \\
\hline S33 & 58.8 & 67.8 & & & \\
\hline S34 & 55.5 & 62.6 & 47.1 & & \\
\hline S35 & 60.3 & 65.8 & 65.8 & 51.7 & \\
\hline
\end{tabular}

A

B 
Table 3

\begin{tabular}{|c|c|c|c|c|c|}
\hline$>150 \mu \mathrm{m}$ dead & S31 & S32 & S33 & S34 & S35 \\
\hline S31 & & & & & \\
\hline S32 & 80.7 & & & & \\
\hline S33 & 85.7 & 82.8 & & & \\
\hline S34 & 78.4 & 81.8 & 80.2 & & \\
\hline S35 & 81.7 & 77.5 & 99.7 & 82.7 & \\
\hline$>150 \mu \mathrm{m}$ dead S31 $1-7 \mathrm{~cm}$ & $1-1,5$ & $2-2,5$ & $2,5-3$ & 4-5 & $6-7$ \\
\hline $1-1,5 \mathrm{~cm}$ & & & & & \\
\hline $2-2,5 \mathrm{~cm}$ & 78.2 & & & & \\
\hline $2,5-3 \mathrm{~cm}$ & 70.7 & 77.8 & & & \\
\hline $4-5 \mathrm{~cm}$ & 81.5 & 76.2 & 75.8 & & \\
\hline $6-7 \mathrm{~cm}$ & 72.2 & 68.1 & 76.8 & 78.3 & \\
\hline
\end{tabular}

Table 4

Table 3. Renkonen's percent similarity index for the living foraminiferal faunas. Table 3A: >150 $\mu \mathrm{m}$ fraction. Table 3B: 63-150 $\mu \mathrm{m}$ fraction. Table 4. Renkonen's percent similarity index for the dead foraminiferal faunas in the $>150 \mu \mathrm{m}$ fraction. Table $4 \mathrm{~A}$ : comparison of the $2-3 \mathrm{~cm}$ level at the five stations. Table 4B: comparison of the 5 depth levels sampled at station S31.

\begin{tabular}{|c|c|c|c|c|c|c|c|c|c|c|c|c|c|c|c|}
\hline$>150 \mu \mathrm{m}$ & \multicolumn{3}{|c|}{ S31 } & \multicolumn{3}{|c|}{ S32 } & \multicolumn{3}{|c|}{ S33 } & \multicolumn{3}{|c|}{ S34 } & \multicolumn{3}{|c|}{ S35 } \\
\hline & $\mathrm{L}$ & D & $\begin{array}{c}\mathrm{L} / \mathrm{T} \\
\text { ratio }\end{array}$ & $\mathrm{L}$ & D & $\begin{array}{c}\mathrm{L} / \mathrm{T} \\
\text { ratio }\end{array}$ & L & D & $\begin{array}{l}\mathrm{L} / \mathrm{T} \\
\text { ratio }\end{array}$ & L & D & $\begin{array}{c}\mathrm{L} / \mathrm{T} \\
\text { ratio }\end{array}$ & L & D & $\begin{array}{l}\mathrm{L} / \mathrm{T} \\
\text { ratio }\end{array}$ \\
\hline Bolivina albatrossi & 4,5 & 3,0 & 60,1 & 0,0 & 8,6 & 0,0 & 0,0 & 5,6 & 0,0 & 0,0 & 2,5 & 0,0 & 9,3 & 3,1 & 74,8 \\
\hline $\begin{array}{l}\text { Bolivina spathulata } \\
\text { Bulimina }\end{array}$ & 1,9 & 11,2 & 14,4 & 0,0 & 14,0 & 0,0 & 0,0 & 11,2 & 0,0 & 0,0 & 23,9 & 0,0 & 2,1 & 12,5 & 14,2 \\
\hline aculeata/marginata & 8,9 & 22,4 & 28,5 & 2,2 & 24,0 & 8,3 & 8,0 & 20,7 & 27,9 & 0,0 & 18,4 & 0,0 & 9,3 & 17,5 & 34,8 \\
\hline Bulimina inflata/costata & 0,0 & 6,3 & 0,0 & 0,0 & 3,0 & 0,0 & 3,1 & 6,4 & 32,7 & 0,0 & 3,1 & 0,0 & 0,0 & 7,1 & 0,0 \\
\hline Chilostomella oolina & 24,1 & 5,3 & 82,0 & 0,0 & 0,8 & 0,0 & 0,0 & 4,3 & 0,0 & 0,0 & 2,3 & 0,0 & 7,0 & 2,7 & 71,8 \\
\hline Globobulimina affinis & 18,8 & 3,2 & 85,5 & 28,3 & 2,4 & 92,2 & 24,0 & 3,7 & 86,7 & 10,0 & 2,5 & 80,1 & 25,6 & 6,7 & 79,3 \\
\hline Uvigerina peregrina & 3,6 & 21,8 & 14,1 & 6,5 & 23,2 & 22,0 & 24,0 & 22,4 & 51,7 & 30,0 & 22,6 & 57,1 & 18,6 & 21,0 & 47,0 \\
\hline Cancris auriculus & 1,8 & 0,0 & 100,0 & 24,0 & 0,2 & 99,2 & 32,0 & 0,0 & 100,0 & 15,0 & 0,0 & 100,0 & 9,3 & 0,2 & 97,9 \\
\hline Karreriella bradyi & 19,6 & 1,3 & 93,8 & 35,0 & 3,2 & 91,6 & 12,0 & 2,7 & 81,6 & 40,0 & 2,9 & 93,2 & 7,0 & 2,2 & 76,1 \\
\hline
\end{tabular}


Table 5. Comparison of living (topmost $3 \mathrm{~cm}$ ) and dead $(2-3 \mathrm{~cm}$ level) foraminiferal assemblages at the five sampling stations. Percentages have been recalculated after omission of all non-fossilising taxa. $L=\%$ in living assemblage, $D=\%$ in dead assemblage, L/T-ratio $=\%$ of living individuals with respect to the total $(L+D)$ assemblage. See text for further explanation.

\section{Appendix}

Appendix 1. Census data for the living benthic foraminiferal fauna in the $>150 \mu \mathrm{m}$ fraction for the five sampling stations.

Appendix 2. Census data for the living benthic foraminiferal fauna in the 63-150 $\mu \mathrm{m}$ fraction for the five sampling stations.

Appendix 3. Census data for the dead benthic foraminiferal faunas in the $>150 \mu \mathrm{m}$ fraction for the five sampling stations. The numbers indicate the total amount of foraminifera found in the whole studied depth interval. 


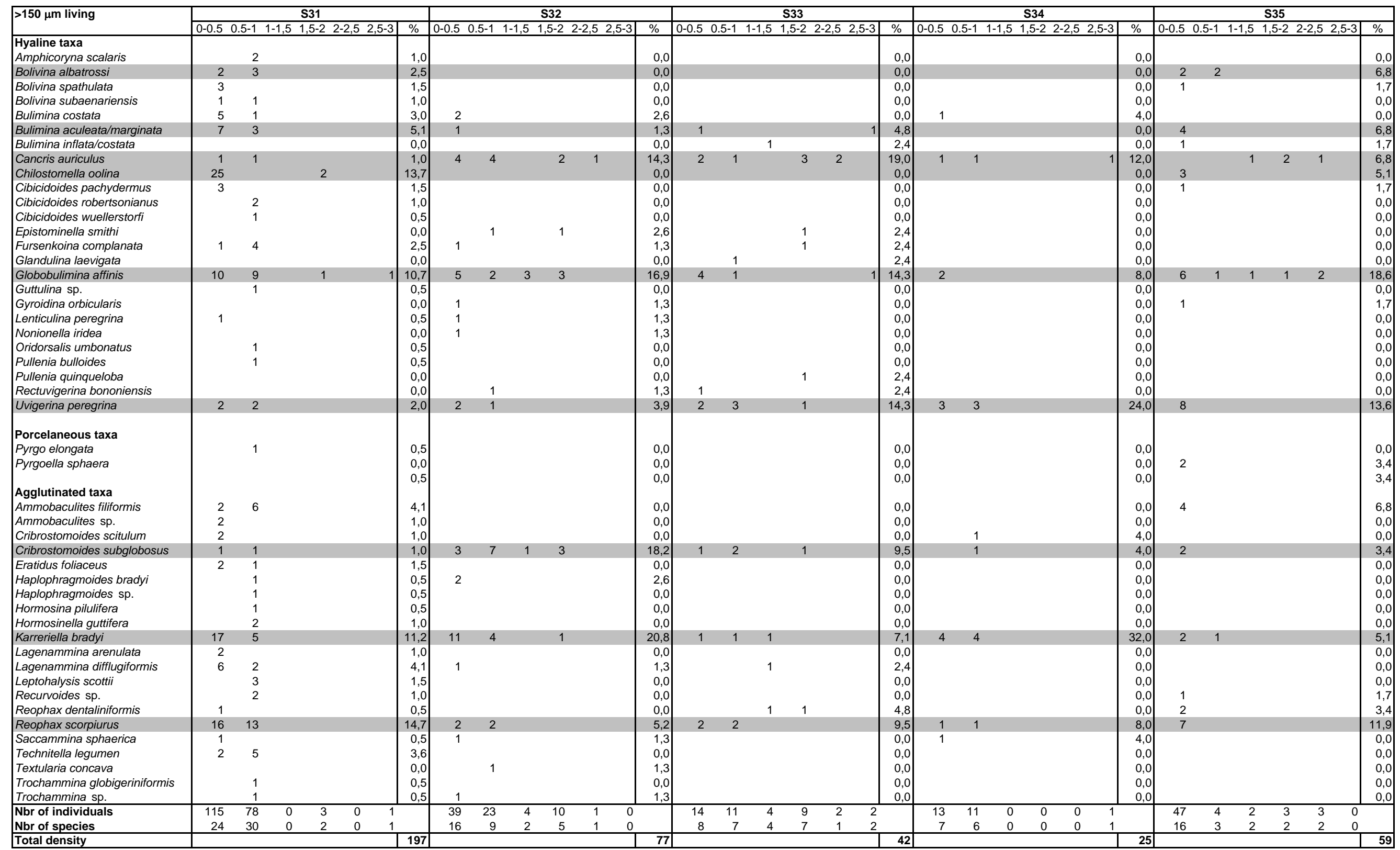




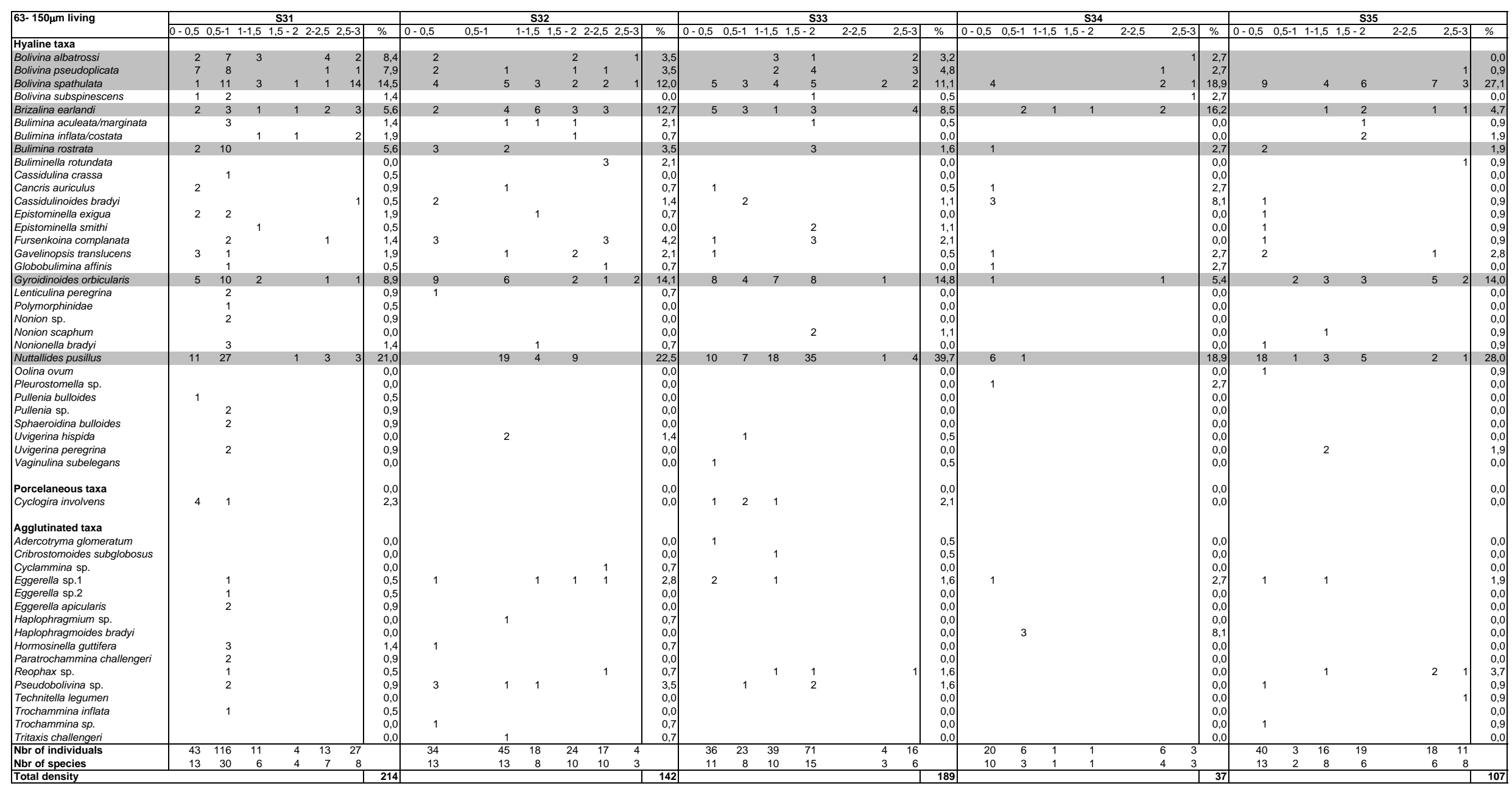




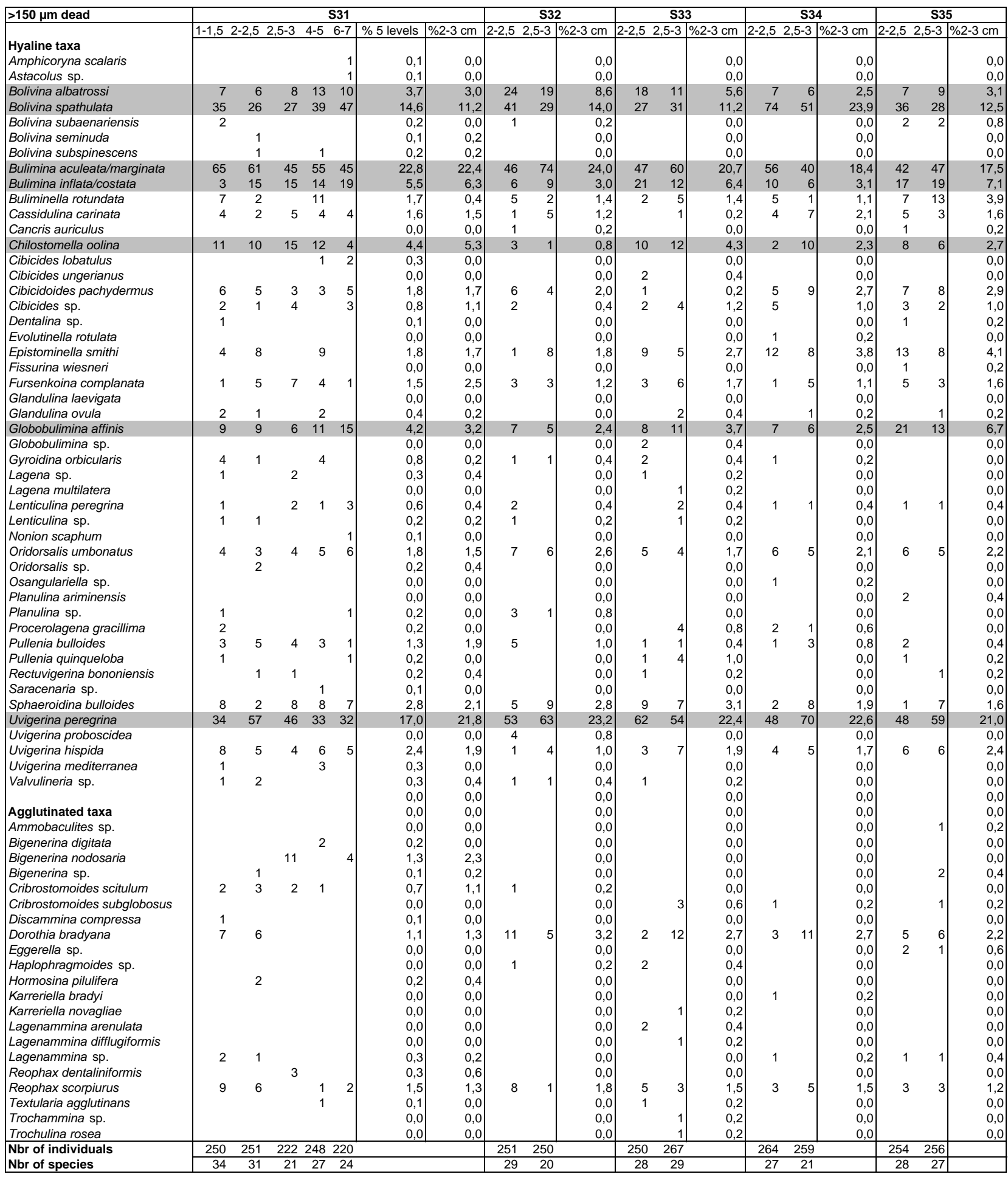

